\title{
Nitrous oxide emission from wetland soil following single and seasonal split application of cattle manure to field tomato (Lycopersicon esculentum, Mill var. Heinz) and rape (Brassica napus, L. var. Giant) crops
}

\author{
Johnson Masaka ${ }^{1,3^{*}}$, Justice Nyamangara ${ }^{2}$ and Menas Wuta ${ }^{3}$
}

\section{*Correspondence:}

johnsonmasaka@yahoo.com; johnsonmasaka@gmail.com; masakaj@msu.ac.zw

${ }^{1}$ Department of Land and Water Resources Management, Faculty of Natural Resources Management and Agriculture, Midlands State University, Private Bag 9055, Gweru, Zimbabwe Full list of author information is available at the end of the article

\begin{abstract}
An understanding of the contribution of manure applications to global atmospheric $\mathrm{N}_{2} \mathrm{O}$ loading is needed to evaluate agriculture's contribution to the global warming process. Two field experiments were carried out at Dufuya wetland $\left(19^{\circ} 17^{\prime} S_{;} ; 9^{\circ} 21^{\prime} \mathrm{E}\right.$, $1260 \mathrm{~m}$ above sea level) to determine the effects of single and split manure applications on emissions of $\mathrm{N}_{2} \mathrm{O}$ from soil during the growing seasons of two rape and two tomato crops. Two field experiments were established. In the first experiment the manure was applied in three levels of 0,15 , and $30 \mathrm{Mg} \mathrm{ha}^{-1}$ as a single application just before planting of the first tomato crop. In the second experiment the 15 and $30 \mathrm{Mg} \mathrm{ha}^{-1}$ manure application rates were divided into four split applications of 3.75 and $7.5 \mathrm{Mg} \mathrm{ha}^{-1}$ respectively, for each of the four cropping events. Single applications of 15 and $30 \mathrm{Mg} \mathrm{ha}^{-1}$ manure once in four cropping events had higher emissions of $\mathrm{N}_{2} \mathrm{O}$ than those recorded on plots that received split applications of 3.75 and $7.5 \mathrm{Mg}$ $\mathrm{ha}^{-1}$ manure at least up to the second test crop. Thereafter $\mathrm{N}_{2} \mathrm{O}$ emissions on plots subjected to split applications of manure were higher or equal to those recorded in plots that received single basal applications of $30 \mathrm{Mg} \mathrm{ha}^{-1}$ applied a week before planting the first crop. Seasonal split applications of manure to wetland vegetable crops can reduce emissions of $\mathrm{N}_{2} \mathrm{O}$ at least up to the second seasonal split application.
\end{abstract}

Keywords: Nitrous oxide, Emission, Manure, Wetland, Vegetable

\section{Background}

In sub-tropical regions of Africa, manures play an important role in soil fertility management through their short-term effects on nutrient supply and long-term contribution to the soil organic matter. The increasing prices of inorganic fertilizers coupled with growing concerns for sustaining soil productivity has led to renewed interest in the use of cattle manures as fertility-restorer inputs (Mutsamba et al. 2012).

Water is one of the most critical factors that limit smallholder crop production in the semi-arid areas of Zimbabwe. About $74 \%$ of the smallholder areas of the country are located in the southern, western and central in Agro-ecological Regions III, IV and V,

(c) 2016 Masaka et al. This article is distributed under the terms of the Creative Commons Attribution 4.0 International License (http://creativecommons.org/licenses/by/4.0/), which permits unrestricted use, distribution, and reproduction in any medium, provided you give appropriate credit to the original author(s) and the source, provide a link to the Creative Commons license, and indicate if changes were made. 
where rainfall is generally low and erratic (300-800 $\left.\mathrm{mm}^{-1}{ }^{-1}\right)$ for reliable dry land cropping by smallholder farmers (Mugandani et al. 2012). The assured availability of water in wetlands which can be extracted without large capital intensive measures has enticed smallholder farmers to intensively utilize wetlands under cropping (Owen et al. 1995). The aerobically composted smallholder cattle manure remains the dominant fertilizer for use by the wetland farmers (Owen et al. 1995).

The addition of cattle manure to wetland soil increases the amount of readily decomposable organic matter associated with high soil microbial activity (Markewich et al. 2010). This enhances the potential for denitrification (Lin et al. 2011) and increased emissions of nitrous oxide $\left(\mathrm{N}_{2} \mathrm{O}\right)$ gas through a general stimulation of microbial respiration, causing rapid oxygen consumption and consequently an increase of anaerobic conditions (Yates et al. 2006; Jassal et al. 2011). Flooded soils in wetlands have aerobic and anaerobic zones, allowing both nitrification and denitrification to take place simultaneously (Johnson et al. 2005, Berdad-Haughn et al. 2006). Since the first process produces the substrate for the second, $\mathrm{N}$ losses can be very high when the two processes are associated (Snyder et al. 2009). As much as $60-70 \%$ of applied $\mathrm{N}$ may be lost as $\mathrm{N}_{2} \mathrm{O}$ (Conrad et al. 1983; Markewich et al. 2010; Kamaa et al. 2011).

Nitrous oxide is a greenhouse and ozone-depleting gas (Mosier and Kroetze 1999; IPCC 2001; Vasileiadou et al. 2011; Mapanda et al. 2012) whose atmospheric concentration is currently $>310 \mathrm{~nL} \mathrm{~L}^{-1}$ and increasing at a rate of approximately $0.4 \%$ per annum (Mosier and Kroetze 1999). It is estimated to account for some $6 \%$ of the greenhouse warming (Ma et al. 2007). Nitrous oxide has a global warming potential of 270-320 times compared to carbon dioxide (Snyder et al. 2009; Smith 2012). Nitrous oxide gas can last 150 years in the atmosphere (Munoz et al. 2010; Saggar 2010). The major sink for $\mathrm{N}_{2} \mathrm{O}$ is the stratospheric reaction with atomic oxygen to $\mathrm{NO}$, which induces the destruction of stratospheric ozone. In addition, gaseous losses of manure $\mathrm{N}$ as $\mathrm{N}_{2} \mathrm{O}$ reduce the amount of $\mathrm{N}$ available to the crop and, therefore, its economic value as fertilizer (Lesschen et al. 2011). Several workers have reported that $\mathrm{N}_{2} \mathrm{O}$ is produced following the breakdown of $\mathrm{N}$ compounds in applied manures (Wrage et al. 2004; Wang et al. 2012; Smith 2012) in soil.

Research during the past several decades has improved our understanding of how $\mathrm{N}_{2} \mathrm{O}$ is produced in agricultural systems, the factors that control its production, source/sink relationships, and gas movement processes. However, despite extensive knowledge of the processes involved, researchers are only beginning to be able to predict the fate of a unit of $\mathrm{N}$ that is applied or deposited on a specific agricultural field (Mosier et al. 2003). Existing data on emissions of $\mathrm{N}_{2} \mathrm{O}$ is extracted from research generated in western Europe, north America and south-east Asia (Kroetze et al. 2003) despite the fact that the tropics and subtropics contribute greatly to the emissions (Billy et al. 2010), particularly since $51 \%$ of world soils are in these climate zones (Mosier et al. 2003). The incorporation of data on $\mathrm{N}_{2} \mathrm{O}$ emissions from African tropical and sub-tropical regions in the near future will lead to realistic and more appropriate emission factors being used by the IPCC (Kroetze et al. 2003). An understanding of the contribution of manure applications to global atmospheric $\mathrm{N}_{2} \mathrm{O}$ loading is needed to evaluate agriculture's contribution to the global warming process (Mapanda et al. 2012). We report in this paper on two field experiments conducted over a period of two seasons in 2007 and 2008. The objective of this study was to quantify the effects of single and seasonal split applications of aerobically decomposed cattle manure 
on $\mathrm{N}_{2} \mathrm{O}$ fluxes from a wetland field during the growing seasons of rape and tomato crops under sub-tropical conditions in Zimbabwe. In this study it was hypothesized that the concentration of mineralized $\mathrm{N}$ in wetland soil, $\mathrm{N}_{2} \mathrm{O}$ emissions, $\mathrm{N}$ uptake and above ground dry matter yield of tomato and rape crops increase with increasing rates of application of aerobically composted cattle manure. It was also hypothesized that seasonal split applications of cattle manure in small doses reduces $\mathrm{N}_{2} \mathrm{O}$ fluxes in soil under rape (Brassica napus, L. var. Giant) and tomato (Lycopersicon esculentum, Mill var. Heinz).

\section{Methods}

\section{Study site description}

The study was conducted between 2007 and 2009 in a typical wetland garden at Dufuya $\left(19^{\circ} 17^{\prime} \mathrm{S} ; 2^{\circ} 21^{\prime} \mathrm{E}, 1260 \mathrm{~m}\right.$ above sea level) wetlands in Chief Sogwala area of Lower Gweru Communal Lands, about $42 \mathrm{~km}$ west of the city of Gweru, Zimbabwe (Fig. 1).

The field experimental site is in Agro-ecological Region III, which receives total rainfall ranging from 650 to $800 \mathrm{~mm}$ per annum (average $725 \mathrm{~mm}$ ) and mean annual temperature is $21{ }^{\circ} \mathrm{C}$ with insignificant frost occurrence in the months of June and July (Mugandani et al. 2012). Rainfall occurs during a single rainy season extending from November to April. The experimental soil is a deeply weathered course textured loamy sand topsoil over sandy loam subsoil derived from granite and classified as Udic Kandiustalf (USDA) and Gleyic Luvisol (FAO) (FAO 1988; Nyamapfene; 1991 Soil Survey Staff 1992). The soil is perennially moist in part of the profile and smallholder farmers have established vegetable gardens along the wetland. Surface runoff and seepage of groundwater from catchment areas over an impermeable substratum towards lower lying areas, together with incident precipitation contribute largely to the water budget of the wetland. Vegetable production is

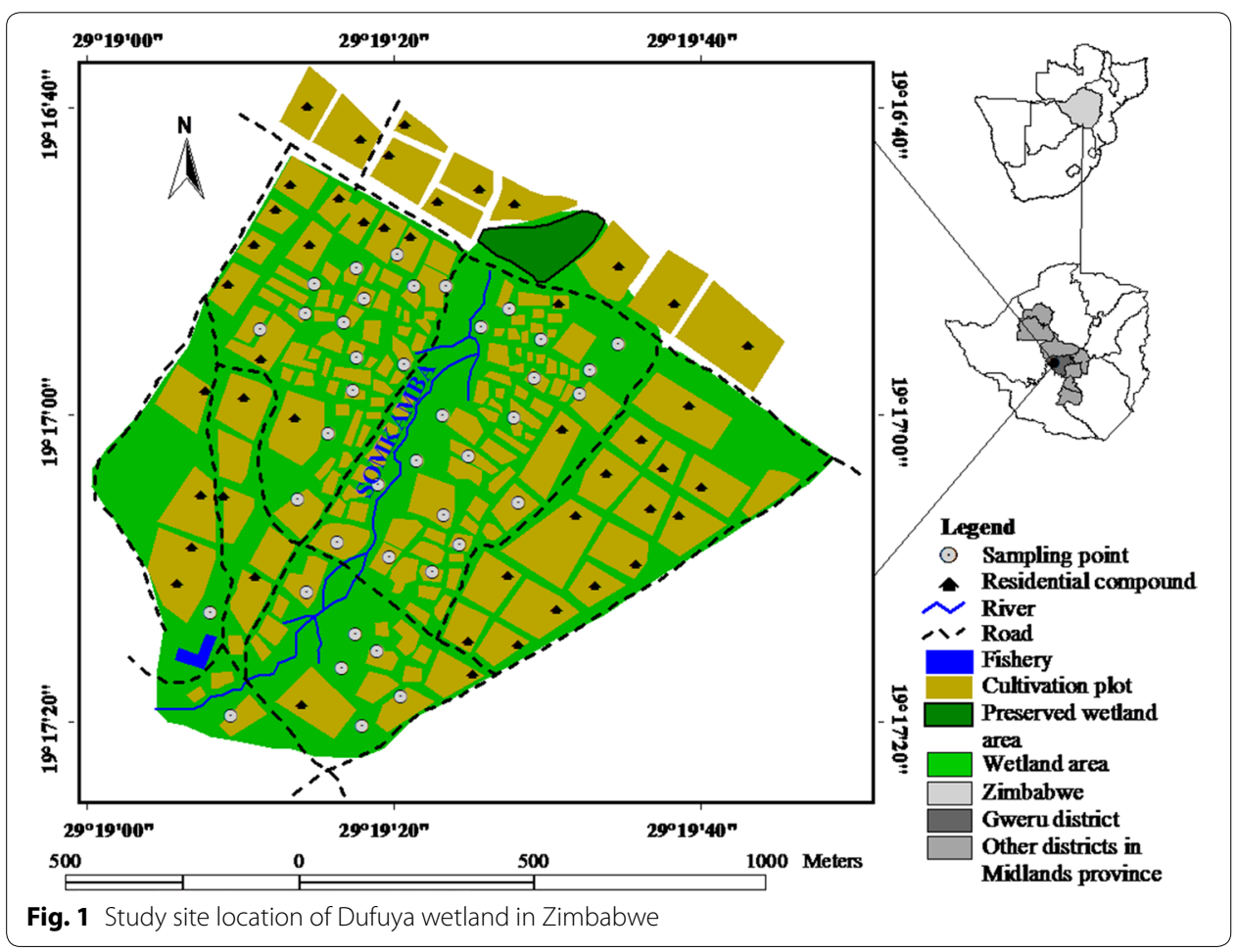


all year round. The site had been under alternate rape, tomato, and maize crops for several years. Rape is cultivated as a leaf vegetable in Zimbabwe (De Lannoy 2001).

\section{Characterization of experimental soil}

Initial soil characterization was done by collecting twenty soil samples from randomly selected points of the field experimental site at a depth of $0-20 \mathrm{~cm}$ using a soil auger. Organic C in soil was determined using the Walkely and Black method (Nelson and Sommers 1996). Soil texture was determined by the Bouyocous hydrometer method (Bouyoucos 1965). Soil bulk density was determined by the core method (Black and Hartge 1986). The soil cores were oven-dried at $105{ }^{\circ} \mathrm{C}$ (to constant weight) for determination of mean gravimetric water content. Taking particle density ( $\mathrm{Pd}$ ) of soil to be $2.65 \mathrm{~g} \mathrm{~cm}^{-3}$ total porosity was calculated and recorded. Total $\mathrm{N}$ in soil was measured by the Kjeldahl method described by Bremner (1996). Results of the analyses are shown in Table 1.

\section{Land preparation and crop management}

The land was prepared by digging using hand hoes to a depth of $30 \mathrm{~cm}$ and then leveling using a rake. Plots raised to a height of $15 \mathrm{~cm}$, which measured $5 \times 1.5 \mathrm{~m}$, were then carefully marked out. The distance between the plots was $60 \mathrm{~cm}$. Small $20 \mathrm{~cm}$ high ridges were established around each plot to avoid cross-contamination by surface runoff. Tomato and rape crops were used as test crops in the study. The cropping sequence in the field experiment was: September-December 2007 first tomato, January-March 2008 first rape, April-July 2008 second tomato and September-November 2008 second rape crops. Spacing between rows was 30 and $15 \mathrm{~cm}$ within the rows for the rape crop. For the tomato crop the plant spacing was $90 \mathrm{~cm}$ between rows and $80 \mathrm{~cm}$ within rows.

\section{Experimental manure}

The smallholder farmers at Dufuya wetlands practice intensive tomato and rape production in small gardens under small scale irrigation (Owen et al. 1995). Because of lack of availability and higher cost of chemical fertilizers, the smallholder farmers have resorted to use of cattle manure which are readily available. The aerobically composted cattle manure used in the field plot experiment was collected from a homestead in the surrounding communal area. High rates of manure applications are used in order to avoid yield depression due to nutrient deficiency (Owen et al. 1995; De Lannoy 2001). Usually, $15 \mathrm{Mg} \mathrm{ha}^{-1}$ of cattle manure is applied by wetland farmers with limited number of cattle $(<6)$. On average, $30 \mathrm{Mg}$ cattle manure $\mathrm{ha}^{-1}$ is applied by wetland farmers with larger

Table 1 Chemical and physical properties of the experimental soil

\begin{tabular}{|c|c|c|c|c|c|c|c|c|c|}
\hline $\begin{array}{l}\text { Soil } \\
\text { depth } \\
(\mathrm{cm})\end{array}$ & $\begin{array}{l}\text { Soil pH } \\
\left(\mathrm{H}_{2} \mathrm{O}\right)\end{array}$ & $\begin{array}{l}\text { Org-C } \\
(\%)\end{array}$ & $\begin{array}{l}{ }^{1} \mathrm{~N} \\
\left(\mathrm{mg} \mathrm{kg}^{-1}\right)\end{array}$ & $\begin{array}{l}\text { Sand } \\
(\%)\end{array}$ & $\begin{array}{l}\text { Clay } \\
(\%)\end{array}$ & $\begin{array}{l}\text { Silt } \\
(\%)\end{array}$ & $\begin{array}{l}\text { Total } \\
\text { porosity } \\
\left(\mathrm{cm}^{3} \mathrm{~cm}^{-3}\right)\end{array}$ & $\begin{array}{l}\text { Bulk } \\
\text { density } \\
\left(\mathrm{g} \mathrm{cm}^{-3}\right)\end{array}$ & $\begin{array}{l}\text { Saturation } \\
\text { gravimet- } \\
\text { ric water } \\
\left(\mathrm{g} \mathrm{g}^{-1}\right)\end{array}$ \\
\hline $0-20$ & 5.5 & 0.4 & 24 & 85 & 10 & 5 & 0.46 & 1.28 & 0.51 \\
\hline $20-60$ & 5.8 & 0.2 & 20 & 80 & 15 & 5 & 0.43 & 1.34 & 0.67 \\
\hline $60-100$ & 5.7 & 0.2 & 20 & 78 & 17 & 5 & 0.41 & 1.39 & 0.69 \\
\hline
\end{tabular}


cattle herds $(>6)$. Smallholder farmers in the wetland may apply these doses once in four cropping events because of the limited annual accumulations of manure in cattle holding pens. In some cases, smaller doses of cattle manure (3-8 $\left.\mathrm{Mg} \mathrm{ha}^{-1}\right)$ in every cropping event are applied by farmers with a smaller herd of cattle. These manure application rates and seasonal split applications were used as treatments in the field experiments in order to capture the common farmer practice and test their effects on loss of $\mathrm{N}$ through $\mathrm{N}_{2} \mathrm{O}$ emissions.

Ten randomly selected samples were collected from a pile of manure and thoroughly mixed in a plastic bucket. Three replicate composite samples were taken for laboratory analysis. The samples were air-dried, passed through a $2 \mathrm{~mm}$ sieve, and analyzed for organic C (Nelson and Sommers 1982), total N using the Kjeidahl procedure (Bremner and Mulvaney 1982), soil, and ash content. Soil and ash contents were determined by ashing manure in a muffle furnace $\left(450{ }^{\circ} \mathrm{C}\right)$ for $16 \mathrm{~h}$. The ash was dissolved in concentrated $\mathrm{HCl}$ acid and separated from mineral soil by filtering. The soil was oven dried and weighed. The selected chemical properties of the experimental manure are shown in Table 2.

\section{Experimental design and treatments}

Two experiments were used to determine the effect of manure application rates and seasonal split applications on $\mathrm{N}_{2} \mathrm{O}$ emission with three treatments for each experiment:

\section{Experiment 1:}

1. Control (unamended);

2. $15 \mathrm{Mg}$ manure $\mathrm{ha}^{-1}$ (applied once in four successive cropping events);

3. $30 \mathrm{Mg}$ manure $\mathrm{N} \mathrm{ha}^{-1}$ (applied once in four successive cropping events).

\section{Experiment 2:}

1. Control (unamended);

2. $15 \mathrm{Mg}$ manure $\mathrm{ha}^{-1}$ (in four seasonal split applications);

3. $30 \mathrm{Mg}$ manure ha ${ }^{-1}$ (in four seasonal split applications).

A randomized complete block design with four replications was employed. The blocking factor was the slope gradient. In Experiment 1, the 15 and $30 \mathrm{Mg}$ manure ha ${ }^{-1}$ were applied once in four cropping events in the respective plots by broadcasting on the surface and then incorporating into the soil just before transplanting the first tomato crop. In Experiment 2, the 15 and $30 \mathrm{Mg} \mathrm{ha}^{-1}$ manure rates, applications were divided into four split seasonal applications over the study period in which two tomato and two rape crops were planted. For the $15 \mathrm{Mg} \mathrm{ha}^{-1}$ cattle manure treatments, the first application

Table 2 Selected chemical properties of the smallholder cattle manure

\begin{tabular}{llllll}
\hline Organic C (\%) & Total N (\%) & C:N ratio & $\begin{array}{l}\text { Soil + ash } \\
\text { content (\%) }\end{array}$ & & \multicolumn{2}{l}{$\begin{array}{l}\text { Soil and ash-free basis } \\
\text { (\%) }\end{array}$} \\
\cline { 5 - 6 } & 1.36 & $16.8: 1$ & 77.18 & Organic C & Total N \\
\hline 22.82 & & & 61.3 & 6.4 \\
\hline
\end{tabular}


of $3.75 \mathrm{Mg} \mathrm{ha}^{-1}$ was done by evenly applying manures in planting rows on the raised plots and then incorporating it a few days before planting the first tomato crop. The balance of three applications of $3.75 \mathrm{Mg} \mathrm{ha}^{-1}$ was applied to each of the remaining three crops in the study by applying into the planting furrows and covering with soil before planting each crop. The same seasonal split application procedure was repeated for the $30 \mathrm{Mg} \mathrm{ha}^{-1}$ manure treatments, which was divided into four applications of $7.5 \mathrm{Mg} \mathrm{ha}^{-1}$ for each of the four crops.

A basal application rate of $1000 \mathrm{~kg} \mathrm{ha}^{-1}$ compound S (5\% N, $7.9 \% \mathrm{P}, 16.6 \% \mathrm{~K}$, and $8 \% \mathrm{~S}$ ) was used in all treatments before planting each crop to capture common fertilizer application practice at Dufuya wetland.

\section{Weather conditions}

Rainfall data were collected daily at $10.00 \mathrm{~h}$ from a rain gauge at the study site. Maximum and minimum daily temperatures at the study site were gap-filled using the department of Agricultural Technical and Extension Services (AGRITEX) meteorological data at Sogwala $\left(19^{\circ} 17^{\prime} \mathrm{S} ; 29^{\circ} 21^{\prime} \mathrm{E}\right)$ rural service centre located $2 \mathrm{~km}$ west of the study site. The meteorological station records daily weather data (Fig. 2).

\section{Static chamber set-up and $\mathrm{N}_{\mathbf{2}} \mathrm{O}$ flux measurement}

Nitrous oxide emissions from soil were trapped using static chamber method described by Holland et al. (1999) and Meyer et al. (2001). There were seven gas sampling campaigns at 14 day interval for the tomato crop. Six gas sampling events were performed

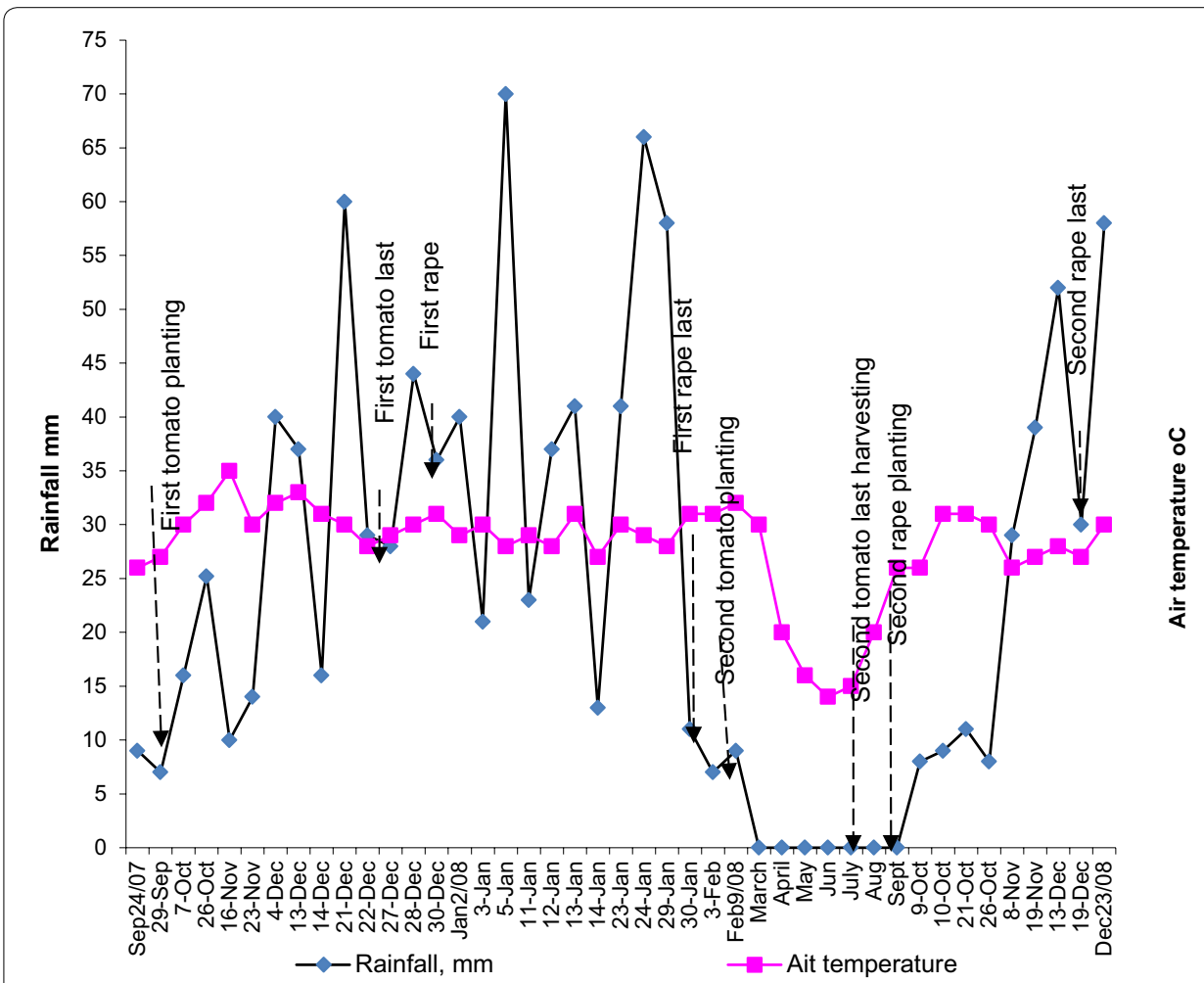

Fig. 2 Daily rainfall, air temperature at the study site 
at 14 day interval for the rape crop. Gas sampling was done at time 0 min to obtain the start values of atmospheric concentration of $\mathrm{N}_{2} \mathrm{O}$ in the static chamber head space and after 30 and 60 min (Mathias et al. 1980; Kaiser et al. 1996). The gas samples were analyzed for $\mathrm{N}_{2} \mathrm{O}$ concentration by means of a Varian Model 3400 gas chromatograph (Walnut Creek, CA, USA) as described by Mosier and Mack (1980) and Galle et al. (2003). Nitrous oxide fluxes (Fn) were calculated using the Hutchinson and Livingston (1993) model:

$$
\mathrm{Fn}=\frac{\delta C n}{\delta t} \cdot \frac{\mathrm{V}}{A} \cdot \frac{\mathrm{Mn}}{V \mathrm{~mol}}
$$

where $\delta C n / \delta t$ is the rate of change in $\mathrm{N}_{2} \mathrm{O}$ concentration $\left(\mu \mathrm{mol} \mathrm{mol} \mathrm{min}^{-1}\right), \mathrm{V}$ is the chamber headspace volume $\left(\mathrm{m}^{3}\right), \mathrm{Mn}$ is the molecular weight of $\mathrm{N}_{2} \mathrm{O}\left(44 \mathrm{~g} \mathrm{~mol}^{-1}\right), \mathrm{A}$ is the surface area $\left(\mathrm{m}^{2}\right)$ and $\mathrm{Vmol}$ is the volume of $1 \mathrm{~mol}$ of gas at $20{ }^{\circ} \mathrm{C}\left(0.024 \mathrm{~m}^{3} \mathrm{~mol}^{-1}\right)$. Further conversions were performed to calculate Fn fluxes in $\mathrm{g} \mathrm{ha}^{-1} \mathrm{day}^{-1}$ as follows (Eq. 2):

$$
\text { Fng ha }{ }^{-1} \text { day }^{-1}=\mathrm{N}_{2} \mathrm{Ogh}^{-1} \cdot 24 \mathrm{~h} \cdot \frac{A}{10000}
$$

Total $\mathrm{N}$ lost as $\mathrm{N}_{2} \mathrm{O}\left(\mathrm{N} \mathrm{kg} \mathrm{ha}^{-1}\right)$ was calculated using Eq. 3:

$$
\mathrm{Nkgha}^{-1}=\text { Fng ha }^{-1} \text { day }^{-1} \cdot \frac{T \text { days }}{1000} \cdot \frac{28}{44}
$$

where $\mathrm{T}$ is the number of days with similar daily $\mathrm{N}_{2} \mathrm{O}$ emissions rates and $28 / 44$ is the conversion ratio for converting $\mathrm{N}_{2} \mathrm{O}$ molar mass to $\mathrm{N}$ content.

\section{Soil mineral $\mathrm{N}$ measurements}

At the same time that gas samples were collected, soil samples $(n=4$ per plot) were also collected from the plots and analyzed for $\mathrm{NH}_{4}-\mathrm{N}$ and $\mathrm{NO}_{3}-\mathrm{N}$. The soil samples were collected from a depth of 0 to $20 \mathrm{~cm}$ using a soil auger. Both analyses were performed using an Alpkem 3550 Flow Injector Analyzer (01 Analytical, College Station, TX, USA) using colorimetric techniques (Robertson et al. 1999).

\section{Dry matter yield}

Four randomly selected plants were chosen and labeled in each plot for crop biomass sampling. All rape leaves and tomato fruits that reached horticultural maturity were harvested from the selected plants at every harvesting event and taken to the laboratory. The samples were rinsed; oven dried at $65^{\circ} \mathrm{C}$ for $24 \mathrm{~h}$ and kept in a dry place. At the end of the growing season, the aboveground biomass of the selected plants was summed up. The composite samples were then ground to pass a $2 \mathrm{~mm}$ sieve and analyzed for $\mathrm{N}$ concentration semi-micro Kjeldahl procedure (Bremner and Mulvaney 1982). Total uptake of $\mathrm{N}$ was determined by multiplying the $\mathrm{N}$ concentration with dry matter yield as follows (Eq. 4):

$$
N \text { uptake } \mathrm{kg} / \mathrm{ha}=[N] \cdot D M
$$

where $[\mathrm{N}]$ is content of $\mathrm{N}$ in $\mathrm{mg} \mathrm{g}^{-1}$ dry matter and $\mathrm{DM}$ is dry matter yield in $\mathrm{T} \mathrm{ha}{ }^{-1}$. 
Mineralized N concentrations in soil were monitored at 2-week internals for each treatment and estimated over 98 and 84 days for tomato and rape crops respectively.

\section{Statistical analysis}

Treatment effects on measured variables in each experiment were analyzed using one way ANOVA (GenStat Discovery Edition 3 2003; GenStat VSNI 2011). Differences between treatment means were judged significant at $\mathrm{p} \leq 0.05$ as determined by Fisher's protected least significant difference (LSD) test. Flux data were log-transformed to normalize the distributions before the statistical analysis. Mean separation was performed using the LSD since there were not $>3$ treatments in each set of experiment. Statistical significance of the differences between measured variables in plots subjected to single and seasonal split manure applications was established by performing t test for unpaired samples using the GenStat package. The Pearson coefficients of determination between measured variables and their $\mathrm{r}^{2}$ values were computed using Microsoft Excel. Significance of correlations between selected variables was established using a linear model GenStat analysis of correlation at $5 \%$ level.

\section{Results}

$\mathrm{NH}_{4}-\mathrm{N}$ concentrations in soil following single and split application of manure

The concentration of $\mathrm{NH}_{4}-\mathrm{N}$ in soil subjected to single application was significantly $(\mathrm{p}<0.05)$ higher than that in soil subjected to seasonal split applications during the growing period of the first tomato and rape crops (Fig. 3a, b). However, only rates of manure applications had a significant $(\mathrm{p}<0.05)$ effect on the differences in the concentrations of $\mathrm{NH}_{4}-\mathrm{N}$ during the growing seasons of the second tomato and rape crops. The effect of single and split application of cattle manure on $\mathrm{NH}_{4}-\mathrm{N}$ concentration was not significant $(p>0.05)$ during the growing period of the second tomato and rape crops (Fig. 3c, d). Except for the first rape crop, $\mathrm{NH}_{4}-\mathrm{N}$ concentrations decreased steadily towards the end of the growing period for each crop.

Single applications of $15 \mathrm{Mg}$ of manure increased the concentration of $\mathrm{NH}_{4}-\mathrm{N}$ in soil by $2.3(30 \%)$ and $2.0 \mathrm{mg} \mathrm{kg}^{-1}$ soil (27 \%) above those recorded on plots amended with the first and second split application of $3.75 \mathrm{Mg}$ manure $\mathrm{ha}^{-1}$ for the first tomato and rape crops, respectively. Single applications of $30 \mathrm{Mg}$ manure ha ${ }^{-1}$ increased $\mathrm{NH}_{4}-\mathrm{N}$ concentration in soil by $2.9(29 \%)$ and $2.3 \mathrm{mg} \mathrm{kg}^{-1}$ soil (21\%) above those recorded in plots subjected to the first and second split 7.5 $\mathrm{Mg} \mathrm{ha}^{-1}$ manure applications for the first tomato and rape crops.

\section{$\mathrm{NO}_{3}-\mathrm{N}$ concentration in soil following single and split application of manure}

Trends for $\mathrm{NO}_{3}-\mathrm{N}$ and $\mathrm{NH}_{4}-\mathrm{N}$ concentrations in soil were comparatively similar during the growing period of test crops. Effects of single and split applications of manure on $\mathrm{NO}_{3}-\mathrm{N}$ were significant $(\mathrm{p}<0.05)$ only up to the second split application while their effects became insignificant ( $\mathrm{p}>0.05)$ in the third and fourth split applications (Fig. 4).

Generally, there were significant temporal variations in the concentrations of $\mathrm{NO}_{3}-\mathrm{N}$ in soil from planting up to the cessation of the growing period of each vegetable crop. Application of $15 \mathrm{Mg} \mathrm{ha}^{-1}$ manure once in four cropping events significantly increased 


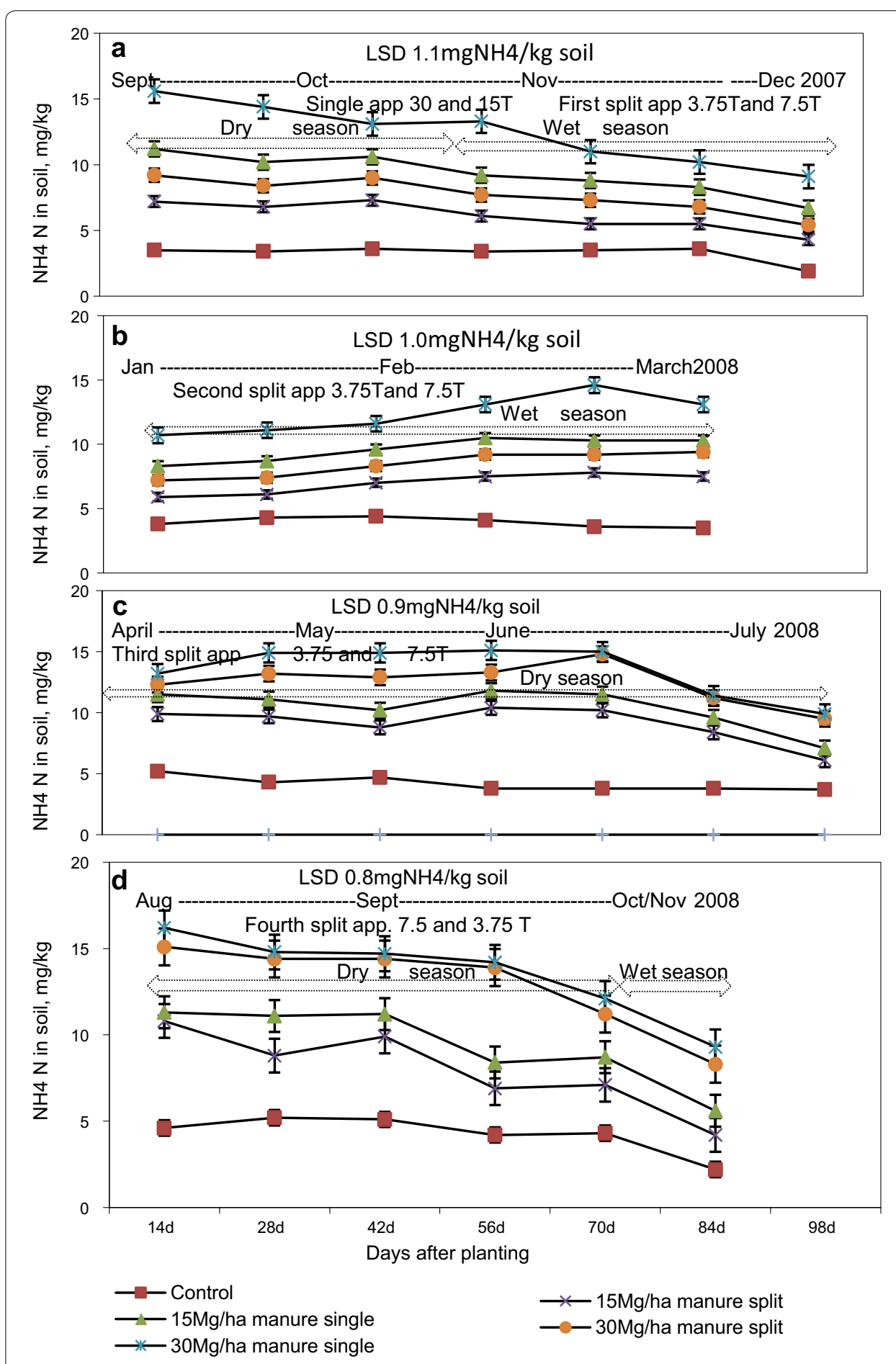

Fig. $3 \mathrm{NH}_{4}-\mathrm{N}$ concentration in wetland soil following single and split application of manure. app application. a First tomato crop, $\mathbf{b}$ first rape crop, $\mathbf{c}$ second tomato crop and $\mathbf{d}$ second rape crop

$(\mathrm{p}<0.05)$ the content of $\mathrm{NO}_{3}-\mathrm{N}$ in wetland soil by $2.4(40 \%)$ and $1.6 \mathrm{mg} \mathrm{kg}^{-1}$ soil $(27 \%)$ above those recorded on plots amended with the first and second split application of $3.75 \mathrm{Mg}$ manure ha ${ }^{-1}$ for the first tomato and rape crops. 
Single applications of $30 \mathrm{Mg}$ manure ha ${ }^{-1}$ significantly $(\mathrm{p}<0.05)$ increased $\mathrm{NO}_{3}-\mathrm{N}$ concentrations in soil by $2.4(27 \%)$ and $1.8 \mathrm{mg} \mathrm{kg}^{-1}$ soil (21\%) above those recorded in plots amended with first and second split $7.5 \mathrm{Mg} \mathrm{ha}^{-1}$ manure for the first tomato and rape crops, respectively. When a single application of 15 and $30 \mathrm{Mg} \mathrm{ha}^{-1}$ manure were used instead of 3.75 and $7.5 \mathrm{Mg} \mathrm{ha}^{-1}$ applied as a third split application mean $\mathrm{NO}_{3}-\mathrm{N}$ concentration differences between the two treatments approached similar levels and were insignificant in the second tomato and rape crops (third and fourth split applications). The mean differences in the concentrations of $\mathrm{NO}_{3}-\mathrm{N}$ in wetland soil between plots amended with single applications at the beginning of the experiment and split applications before planting the successive test crops progressively became narrower towards the end of the experiment.

\section{Nitrous oxide fluxes from soil following single and split application of manure}

Results show that the rate of cattle manure applications exerted significant differences $(\mathrm{p}<0.05)$ in $\mathrm{N}_{2} \mathrm{O}$ fluxes following single and seasonal split manure applications throughout the study period (Fig. 5). Nevertheless, split application of manure exerted significant $(\mathrm{p}<0.05)$ effect on $\mathrm{N}_{2} \mathrm{O}$ emissions within the growing periods of the first tomato and rape crops only (Fig. 4a, b) when compared with the control.

Considerably higher $\mathrm{N}_{2} \mathrm{O}$ emissions were observed in the first gas samples collected from vegetable plots amended with single applications of $30 \mathrm{Mg} \mathrm{ha}^{-1}$ manure, which was applied a week before planting the first tomato crop. In single manure applications, elevated $\mathrm{N}_{2} \mathrm{O}$ fluxes persisted throughout the 98 and 84-day period for tomato and rape crops respectively. In split applications of manure, $\mathrm{N}_{2} \mathrm{O}$ fluxes remained constant or gradually decreased despite additions of cattle manure before each planting event.

Single applications of $15 \mathrm{Mg}$ manure ha ${ }^{-1}$ increased $\mathrm{N}_{2} \mathrm{O}$ fluxes by $1.8(36 \%)$ and $2.7 \mathrm{~g} \mathrm{ha}^{-1} \mathrm{day}^{-1}(43 \%)$ above those recorded from plots subjected to the first and second split application of $3.75 \mathrm{Mg}$ manure $\mathrm{ha}^{-1}$ applied a week before planting the first crop for the tomato and rape crops, respectively. The same practice at $30 \mathrm{Mg}$ manure ha $^{-1}$ application levels increased $\mathrm{N}_{2} \mathrm{O}$ fluxes on wetland soil by $2.5(38 \%)$ and $3.1 \mathrm{~g} \mathrm{ha}^{-1}$ day $^{-1}$ (34\%).

\section{Soil factors $-\mathrm{N}_{\mathbf{2}} \mathrm{O}$ emission relationships}

The concentrations of $\mathrm{NH}_{4}-\mathrm{N}$ and $\mathrm{NO}_{3}-\mathrm{N}$ in soil are important predictors of $\mathrm{N}_{2} \mathrm{O}$ fluxes in soil (Figs. 6, 7). Regression analysis between measured variables after split and single application of cattle manure are shown in Figs. 6 and 7. Results show significant correlations $(\mathrm{p}<0.05)$ between $\mathrm{NO}_{3}-\mathrm{N} ; \mathrm{NH}_{4}-\mathrm{N}$; soil moisture and emissions of $\mathrm{N}_{2} \mathrm{O}$. Coefficients of regression in the correlations between soil moisture and $\mathrm{N}_{2} \mathrm{O}$ emissions varied between 0.26 and 0.69 (Figs. 6e, f, 7a, b). The coefficients of regression $\left(\mathrm{r}^{2}\right)$ values for the positive linearity in the relationships between $\mathrm{NH}_{4}-\mathrm{N}$ concentrations in soil and $\mathrm{N}_{2} \mathrm{O}$ emissions ranged from 0.42 to 0.78 after split and single manure application. The coefficients of determination in the relationships between $\mathrm{NO}_{3}-\mathrm{N}$ in soil and $\mathrm{N}_{2} \mathrm{O}$ fluxes on soil varied between 0.47 and 0.77 . The $\mathrm{r}^{2}$ values the relationships between $\mathrm{NH}_{4}-\mathrm{N}$, $\mathrm{NO}_{3}-\mathrm{N}$ in soil and emissions of $\mathrm{N}_{2} \mathrm{O}$ were comparatively similar. 


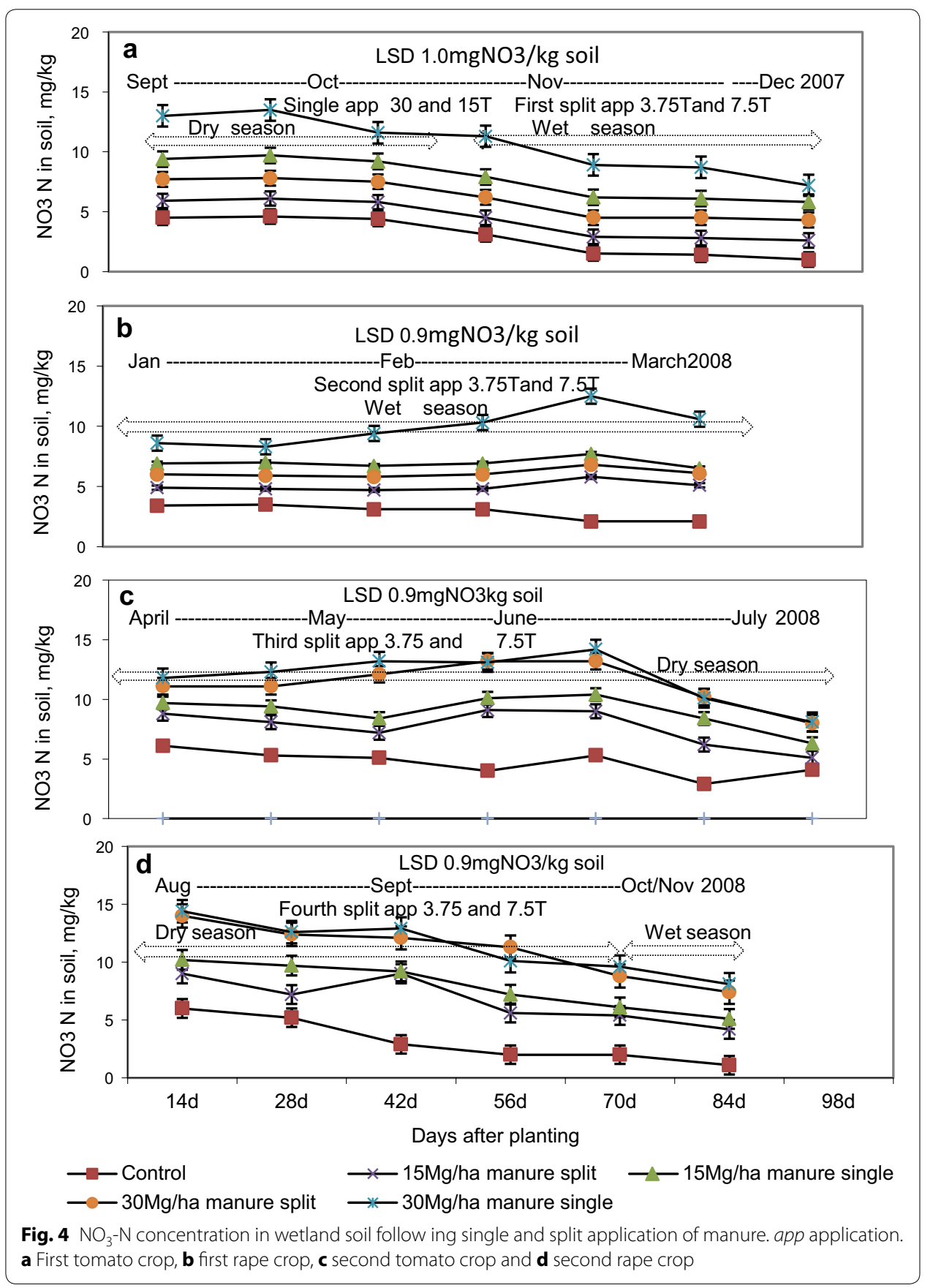

\section{Aboveground dry matter yield and $\mathrm{N}$ uptake following split and single application of manure}

Dry matter yield and $\mathrm{N}$ uptake following seasonal split and single application of manure are shown in Tables 3 and 4 . The effects of single and split applications of manure on $\mathrm{N}$ uptake were significant $(\mathrm{p}<0.05)$ for all vegetable crops. However, the differences in dry matter yield between plots subjected to single applications and those amended with the first split applications were larger than those recorded between single manure applied plots and the plots amended with the fourth split application of manure. 


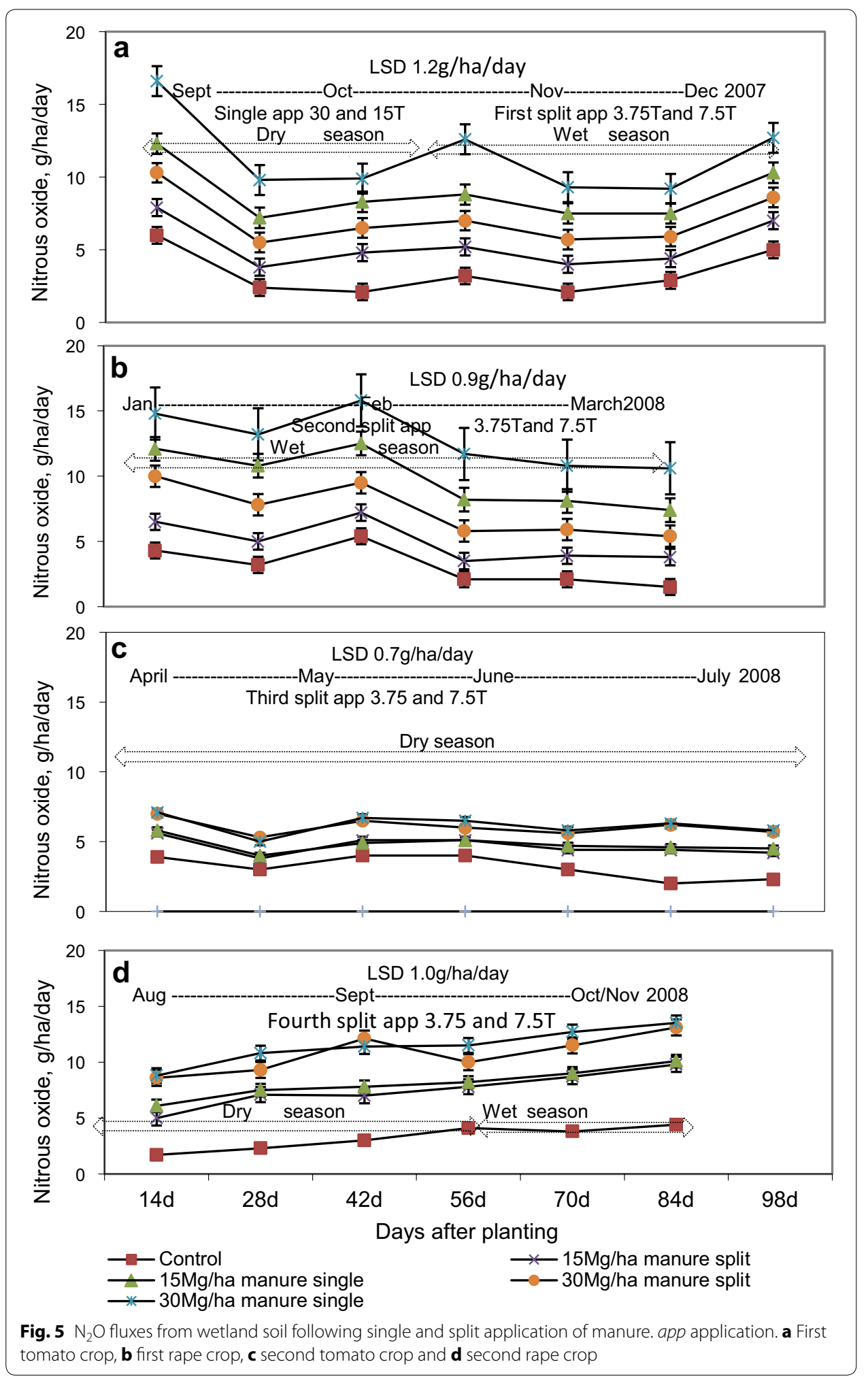

$\mathrm{N}$ uptake was lowest in the control plots and highest in plots that received $30 \mathrm{Mg}$ manure as a single application. Plots amended with split applied manure recorded substantial reductions in $\mathrm{N}$ uptake when compared with those recorded on plots amended 

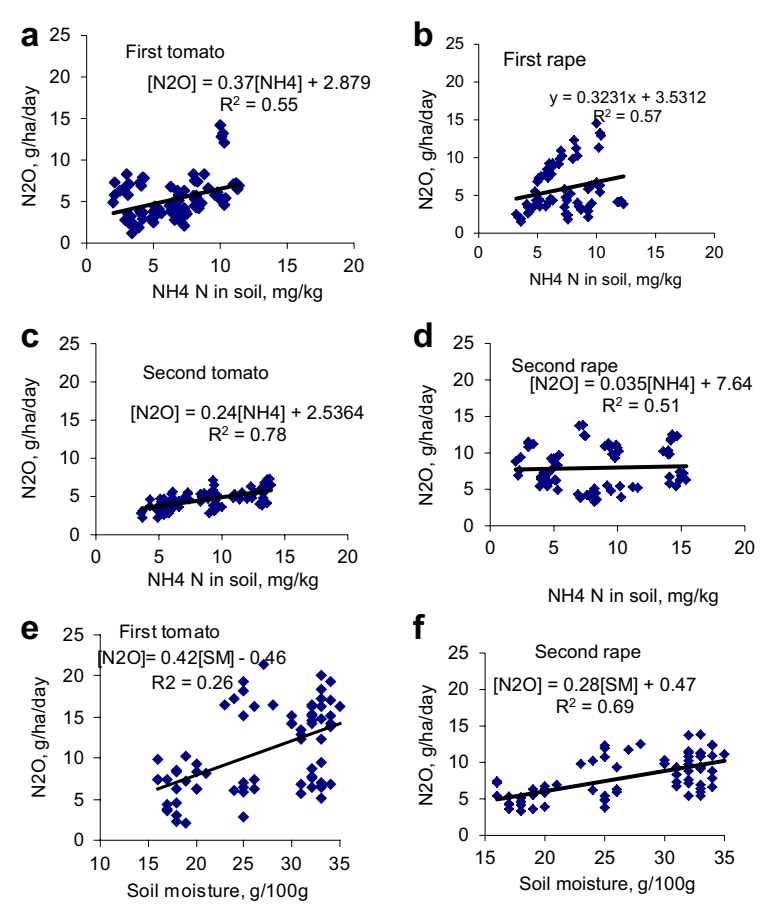

f
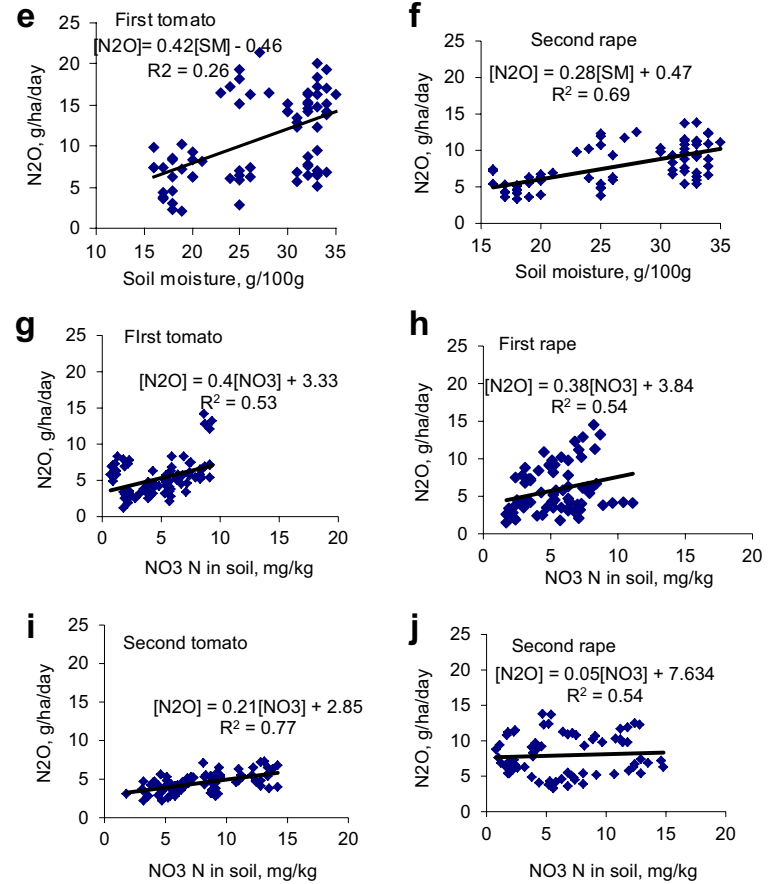

Fig. 6 Regression analyses showing relationships between mineral $\mathrm{N}_{1} \mathrm{~N}_{2} \mathrm{O}$ and wetland soil moisture after split application of manure

with single manure applications. When 15 and $30 \mathrm{Mg}$ manure ha $^{-1}$ were applied once, $\mathrm{N}$ uptake increased by $48.3 \mathrm{~kg} \mathrm{ha}^{-1}$ or $59 \%$ and $102 \mathrm{~kg} \mathrm{~N} \mathrm{ha}^{-1}$ or $67 \%$ in excess of those recorded in plots amended with the first split applications of 3.75 and $7.5 \mathrm{Mg}$ manure $\mathrm{ha}^{-1}$, respectively.

The second tomato crop experienced increase of $\mathrm{N}$ uptake of $63.4 \mathrm{~kg} \mathrm{ha}^{-1}$ or $51 \%$ and $76.0 \mathrm{~kg} \mathrm{ha}^{-1}$ or $43 \%$ in plots subjected to single applications of 15 and $30 \mathrm{Mg}$ manure $\mathrm{ha}^{-1}$ in comparison with those observed in plots amended with the third split applications of 3.75 and $7.5 \mathrm{Mg}$ manure $\mathrm{ha}^{-1}$ respectively.

While $\mathrm{N}$ uptake responses to single applications of 15 and $30 \mathrm{Mg}$ high $\mathrm{N}$ manure ha ${ }^{-1}$ were $37-67 \%$ above those in plots subjected to split applications of 3.75 and $7.5 \mathrm{Mg}$ 

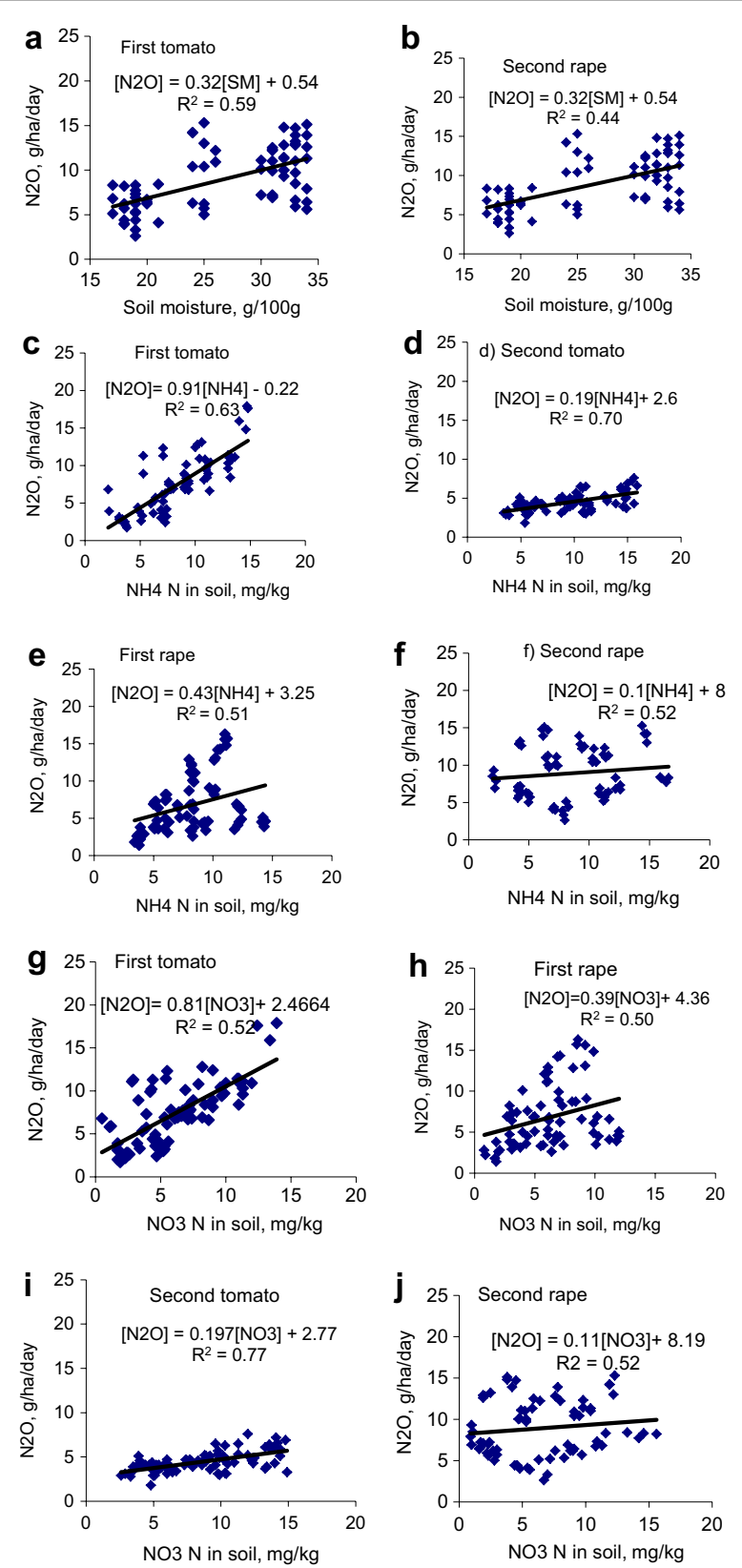

Fig. 7 Regression analyses showing relationships between mineral $\mathrm{N}_{1} \mathrm{~N}_{2} \mathrm{O}$ and wetland soil moisture after a single application of manure

manure $\mathrm{ha}^{-1}$ for the three previous crops, the same soil fertilization practice could increase $\mathrm{N}$ uptake by only $3.4 \mathrm{~kg} \mathrm{ha}^{-1}$ or $4 \%$ and $10.5 \mathrm{~kg} \mathrm{ha}^{-1}$ or $7 \%$ respectively for the last crop in the study.

Single applications of high $\mathrm{N}$ manure at $15 \mathrm{Mg} \mathrm{ha}^{-1}$ stimulated an increase of 51, 11,42 , and $19 \%$ in dry matter yield in excess of those recorded on plots subjected to the first, second, third and fourth split applications of high $\mathrm{N}$ manure. The application of $30 \mathrm{Mg}$ manure $\mathrm{ha}^{-1}$ once during the study period caused an increase in dry matter 


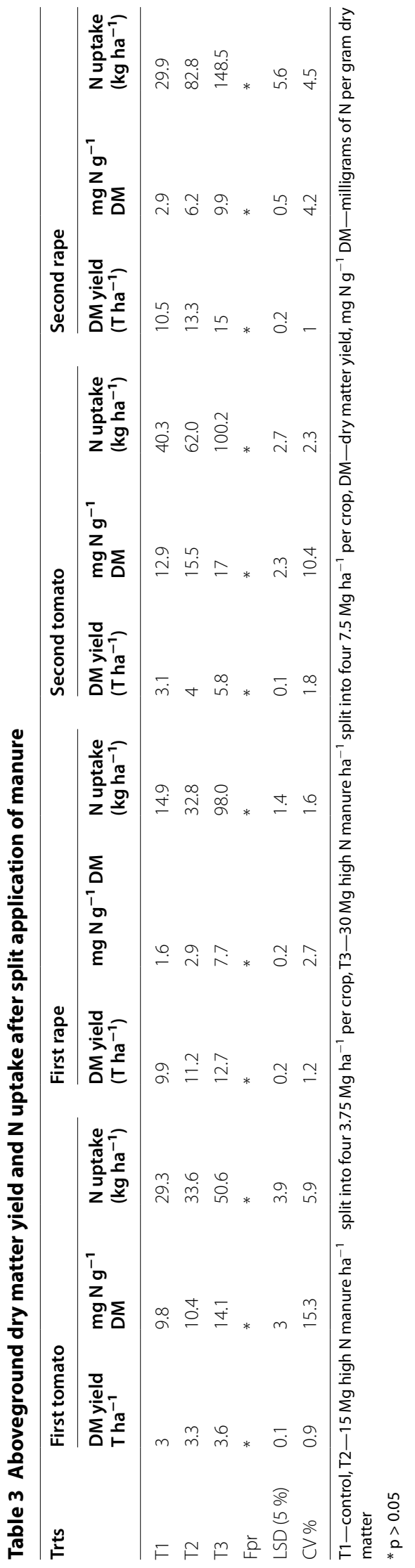




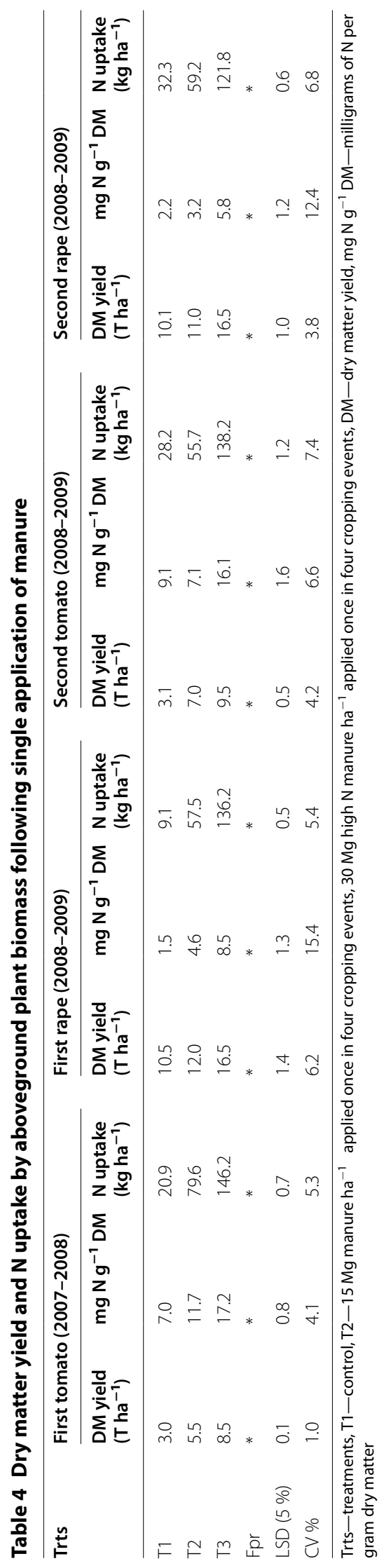


yield of 58,23, 23, and $9 \%$ during the first, second, third and fourth split application of $7.5 \mathrm{Mg} \mathrm{ha}^{-1}$ manure.

\section{Total $\mathbf{N}$ lost as nitrous oxide}

Tables 5 and 6 shows estimated losses of $\mathrm{N}$ in $\mathrm{N}_{2} \mathrm{O}$ emission after seasonal split and single applications of manure to rape and tomato crops. Single applications of cattle manure had a significant effect on losses of $\mathrm{N}_{2} \mathrm{O}$ from soil throughout the growing period of tomato and rape crops (Table 4). The effect of split applications of manure on emissions of $\mathrm{N}_{2} \mathrm{O}$ were significant $(\mathrm{p}<0.05)$ during the growing period of the first tomato and rape crops only (Table 3 ). Thereafter, the rates of application rather than the factors of single and seasonally split manure applications had significant effect on total $\mathrm{N}$ lost through $\mathrm{N}_{2} \mathrm{O}$ emissions. Losses of $\mathrm{N}$ through $\mathrm{N}_{2} \mathrm{O}$ emission on plots amended with split applications of manure were $23-138 \%$ above the losses recorded on the control plots. Estimated total $\mathrm{N}$ lost through $\mathrm{N}_{2} \mathrm{O}$ emissions on plots subjected to single applications of manure were 121 and $134 \%$ above the emissions recorded on control plots. Amongst the manure amended plots, lower $\mathrm{N}$ losses of $\mathrm{N}_{2} \mathrm{O}$ emission were recorded in the second tomato, a crop which grew under dry weather conditions of the 2008 April-July winter season.

When $15 \mathrm{Mg} \mathrm{ha}^{-1}$ of manure were applied once in the four cropping events $\mathrm{N}_{2} \mathrm{O}$ emission increased by 31 and $38 \%$ above those recorded from plots subjected to the first and second split application of $3.75 \mathrm{Mg}$ manure $\mathrm{ha}^{-1}$ applied a week before planting the first tomato and rape crops, respectively. Mean differences in total $\mathrm{N}$ lost as $\mathrm{N}_{2} \mathrm{O}$ emission between plots amended with a single basal application of $30 \mathrm{Mg}$ of manure and those amended with the first and second seasonally split application of 7.5 Mg manure $\mathrm{ha}^{-1}$ were 39 and $13 \%$ for the first tomato and rape crops respectively. As the study approached the last cropping event, mean differences in the loss of $\mathrm{N}$ through $\mathrm{N}_{2} \mathrm{O}$ emissions between plots amended with single basal applications and those that received seasonally split applications became progressively smaller and insignificant.

When 15 and $30 \mathrm{Mg}$ manure $\mathrm{ha}^{-1}$ were applied once in four cropping events 0.4 and $0.9 \%$ of applied $\mathrm{N}$ was lost as $\mathrm{N}_{2} \mathrm{O}$, respectively, during the growing period of the first tomato crop. When 15 and $30 \mathrm{Mg}$ of manure were split applied into four applications of 3.75 and $7.5 \mathrm{Mg} \mathrm{ha}^{-1}$ to every crop total $\mathrm{N}$ losses in $\mathrm{N}_{2} \mathrm{O}$ emission represented 0.9 and $0.9 \%$ (for the rape crop); 0.8 and $0.6 \%$ (for the tomato crop) of applied N. Generally, the proportion of applied $\mathrm{N}$ lost as $\mathrm{N}_{2} \mathrm{O}$ was higher in the rape crop than in the tomato crop.

\section{Total $\mathrm{N}$ lost in $\mathrm{N}_{\mathbf{2}} \mathrm{O}$ emission per unit dry matter}

Table 7 shows $\mathrm{N}$ lost in $\mathrm{N}_{2} \mathrm{O}$ emission per unit of harvested dry matter yield after the single application of cattle manure in four vegetable cropping events. When the application rates of manure were increased from 15 to $30 \mathrm{Mg} \mathrm{ha}^{-1}$, the emissions of $\mathrm{N}_{2} \mathrm{O}$ per unit harvested dry matter of rape and tomato significantly decreased $(\mathrm{p}<0.05)$. The estimated loss of $\mathrm{N}$ in $\mathrm{N}_{2} \mathrm{O}$ emissions decreased by $0.01-0.03$ and $0.01-0.06 \mathrm{~kg} \mathrm{~N}-\mathrm{N}_{2} \mathrm{O}$ per $\mathrm{T}$ of harvested dry matter when manure application rates were increased from 15 to $30 \mathrm{Mg} \mathrm{ha}^{-1}$, respectively. Nitrous oxide emission losses per unit harvested dry matter of tomato crop were significantly $(\mathrm{p}<0.05)$ higher in the unamended plots than on manure fertilized plots (Table 7). However, losses of $\mathrm{N}$ in $\mathrm{N}_{2} \mathrm{O}$ emissions per unit harvested dry 


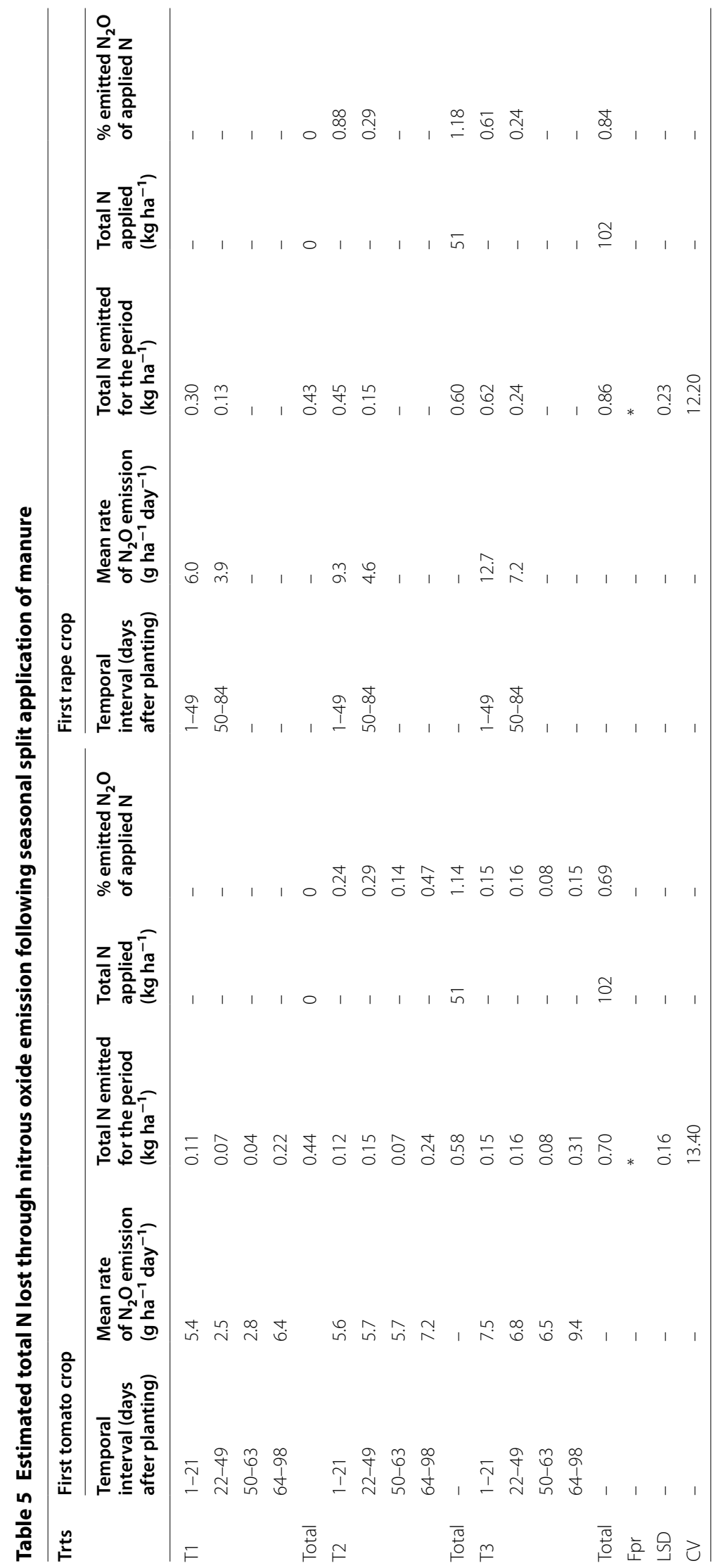




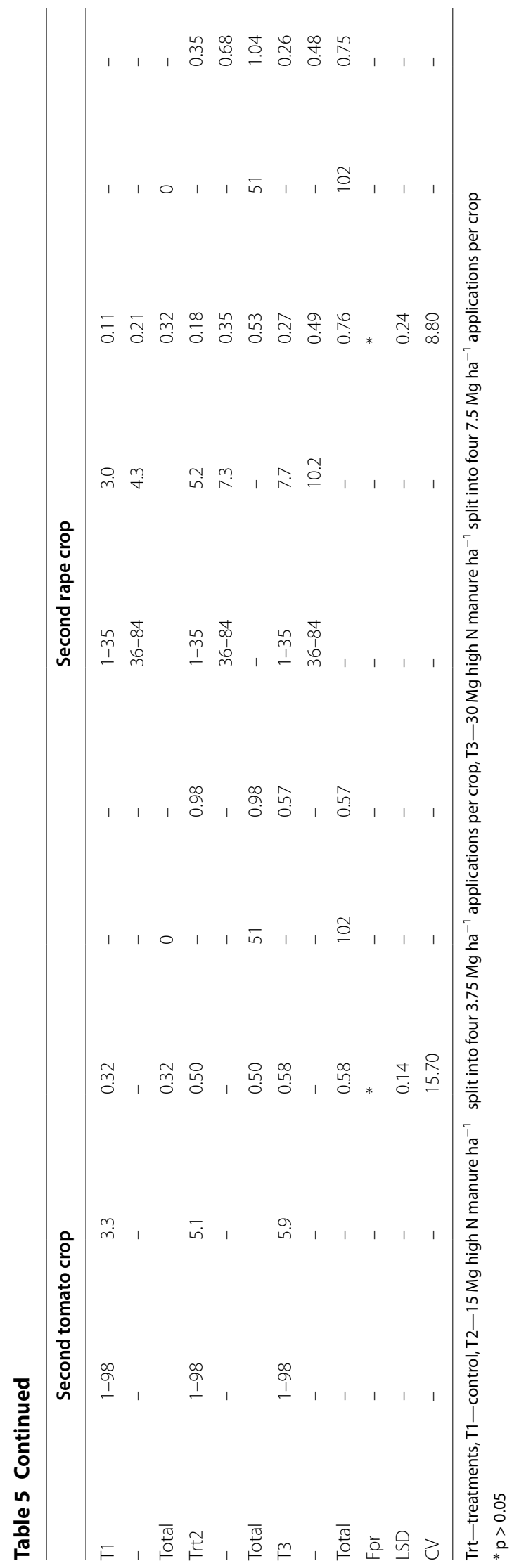




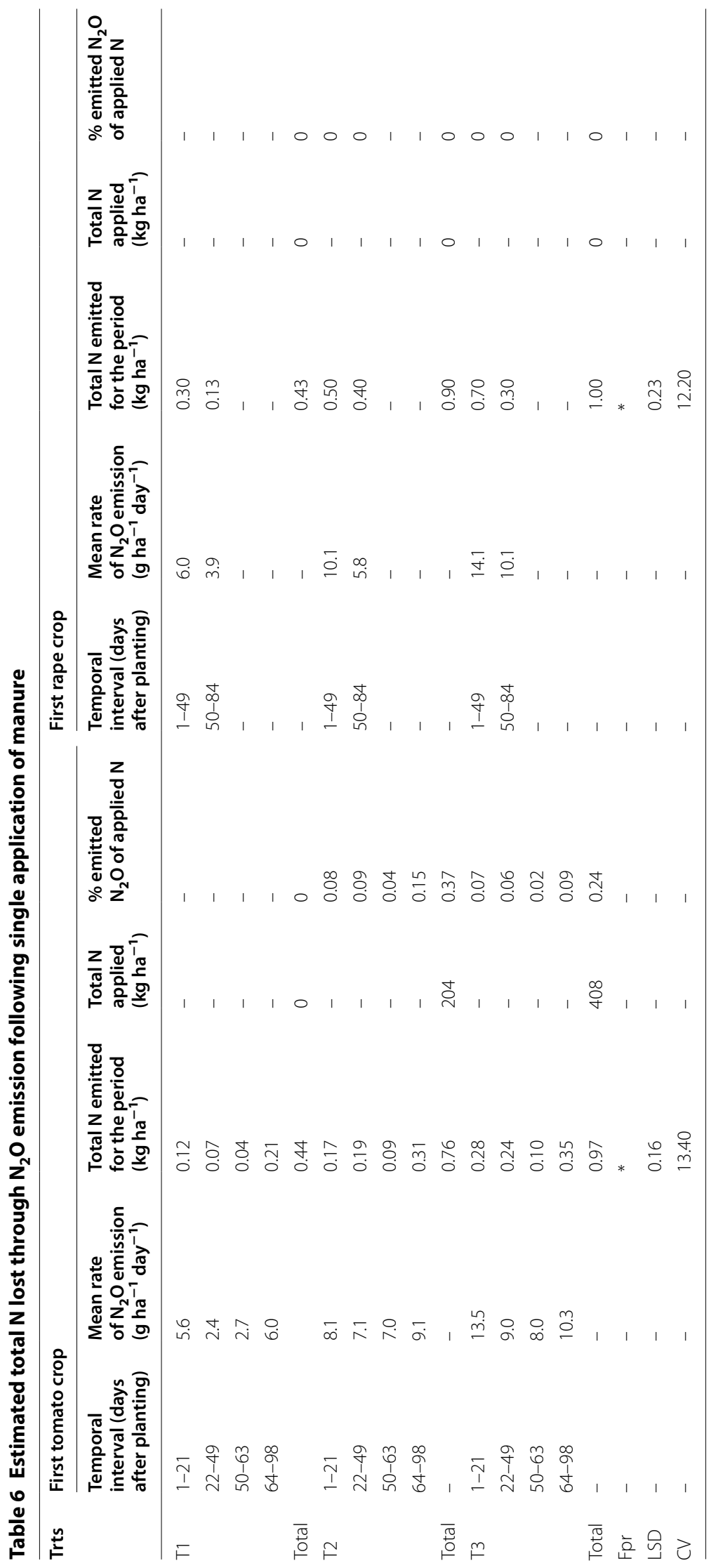




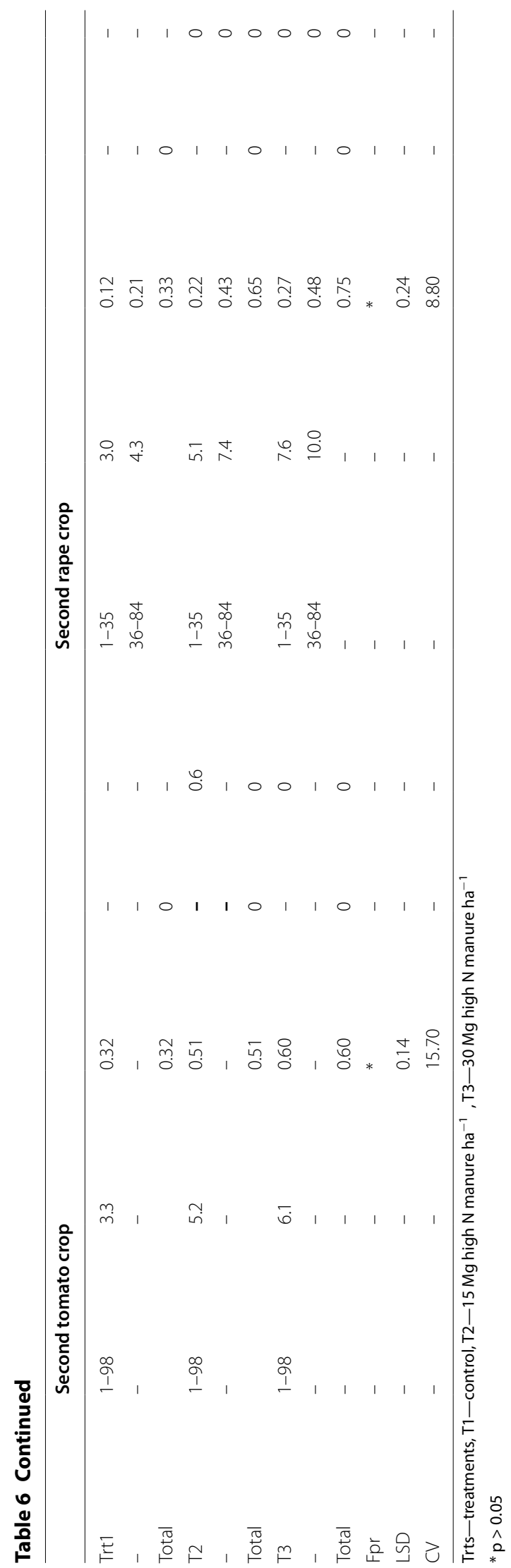




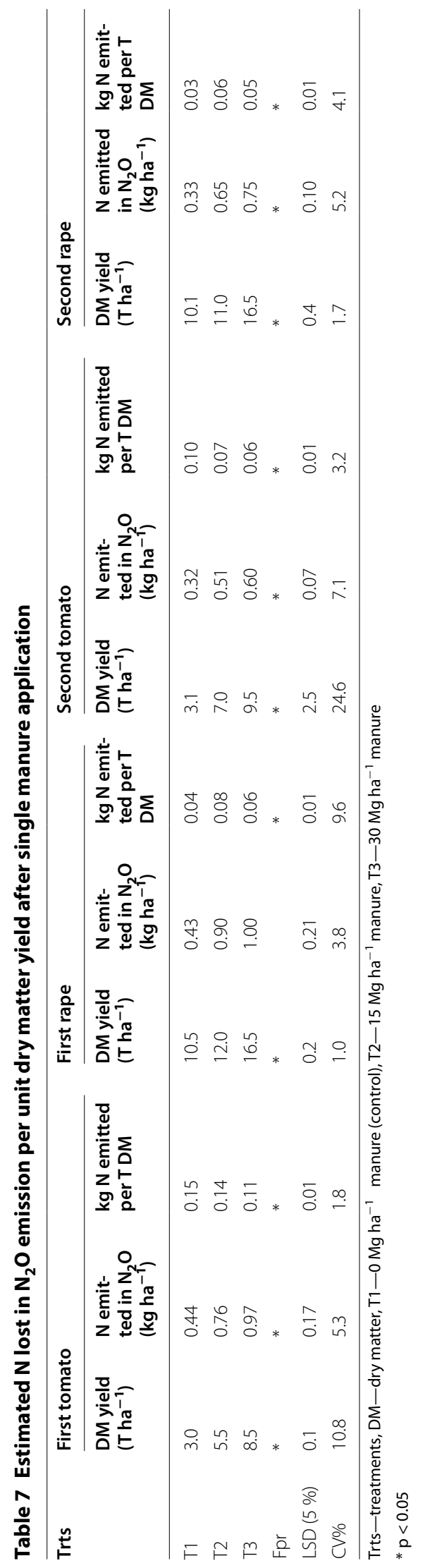


matter from the control plots under rape crop were generally lower when compared with the losses from manure fertilized plots.

\section{Discussion}

Effect of seasonal split and single manure application on soil mineral $\mathrm{N}$ and $\mathrm{N}_{2} \mathrm{O}$ emission Wetland smallholder farmers in subtropical Africa commonly apply manure in small doses in each vegetable cropping event while others apply large doses once in 3-4 cropping occasions. Results in this study have clearly demonstrated that small dose manure application per crop can only reduce losses of $\mathrm{N}$ by gaseous emissions of $\mathrm{N}_{2} \mathrm{O}$ at least up to the second cropping event. This trend in the $\mathrm{N}_{2} \mathrm{O}$ flux responses to the treatments clearly suggested that the single applications of 15 and $30 \mathrm{Mg}$ manure ha ${ }^{-1}$ provided substantially higher masses of organic substrate (Markewich et al. 2010) for the microbial degradation processes in aerated macro-pores of the soil profile during the first two vegetable cropping events. In studies related to $\mathrm{N}$ transformations in soils Markewich et al. (2010) reported significant accumulations of mineralized $\mathrm{N}\left(\mathrm{NH}_{4}-\mathrm{N}\right.$ and $\left.\mathrm{NO}_{3}-\mathrm{N}\right)$ in microbially driven organic matter decomposition. Upon flooding of the macro-pores with soil water in the wetland (Johnson et al. 2005; Berdad-Haughn et al. 2006) some of the $\mathrm{NO}_{3}-\mathrm{N}$ is subjected to denitrification (Ma et al. 2007) associated with emissions of $\mathrm{N}_{2} \mathrm{O}$ in soil. In addition to that, the application of cattle manure to wetland soil enhances its potential for emissions of $\mathrm{N}_{2} \mathrm{O}$ gas by stimulating increased microbial respiration, causing rapid oxygen consumption and consequently an increase of anaerobic conditions for the onset of denitrification processes (Yates et al. 2006; Jassal et al. 2011). Wetland soils have aerobic and anaerobic sites that allow nitrification and denitrification to take place simultaneously (Johnson et al. 2005). Since the first process produces the substrate for the second, $\mathrm{N}$ losses through emissions of $\mathrm{N}_{2} \mathrm{O}$ can be high when the two processes are associated (Snyder et al. 2009). Evidently, the application of cattle manure to wetland cropping systems has the potential of increasing the contribution of agriculture to atmospheric $\mathrm{N}_{2} \mathrm{O}$ loading (Markewich et al. 2010; Kamaa et al. 2011).

The mean differences in the rates of $\mathrm{N}_{2} \mathrm{O}$ emissions between plots amended with single basal applications and those that received split applications became progressively smaller and insignificant $(\mathrm{p}>0.05)$ towards the last test crop. The decline in the vegetable plots that received single basal manure applications in evolving elevated amounts of $\mathrm{N}_{2} \mathrm{O}$ over those that received seasonal split manure amendments is attributed to the rapid decrease in the capacity of the plots that received single manure amendments to supply $\mathrm{NO}_{3}-\mathrm{N}$, which is a substrate for the microbes that participate in the denitrification process. This decline in the content of mineralised $\mathrm{N}$ is a consequent of successive $\mathrm{N}$ uptake without replenishments, immobilization in ligno-protein complexes of humus formation (Yates et al. 2006), $\mathrm{N}_{2} \mathrm{O}$ gas evolving denitrification (Kamaa et al. 2011; Lesschen et al. 2011), and migration of $\mathrm{NO}_{3}-\mathrm{N}$ to ground water resources (Mapanda et al. 2012).

Results from the regression analysis implied that soil mineral $\mathrm{N}$ concentrations $\left(\mathrm{NH}_{4}-\mathrm{N}\right.$ and $\left.\mathrm{NO}_{3}-\mathrm{N}\right)$ displayed significant $(\mathrm{p}<0.05)$ influence on the variability found in $\mathrm{N}_{2} \mathrm{O}$ emission. Both processes of nitrification of $\mathrm{NH}_{4}-\mathrm{N}$ and denitrification of $\mathrm{NO}_{3-}$ $\mathrm{N}$ are thought to contribute immensely to the emissions of $\mathrm{N}_{2} \mathrm{O}$ although the later has been suggested to play a bigger role in the emissions (Ma et al. 2007; Smith 2012). In this 
study, $\mathrm{NH}_{4}-\mathrm{N}$ and $\mathrm{NO}_{3}-\mathrm{N}$ exerted comparatively equal influence on the variability found in $\mathrm{N}_{2} \mathrm{O}$ emissions in surface soil $\left(\mathrm{r}^{2}=0.51-0.55\right.$ vs. $0.52-0.53$ for first tomato crop; $\mathrm{r}^{2}=0.51-0.57$ vs. $0.50-0.53$ for first rape crop; $\mathrm{r}^{2}=0.42-0.78$ vs. $0.47-0.77$ for second tomato crop; $\mathrm{r}^{2}=0.51-0.52$ vs. $0.52-0.54$ for second rape crop). The first stage in the decomposition of $\mathrm{N}$-containing organic materials in applied manure produces ammoniacal $\mathrm{N}$ which is a substrate for the second process involving nitrification. Nitrogen losses in $\mathrm{N}_{2} \mathrm{O}$ emissions can be very high when the two processes are associated. As much as $60-70 \%$ of fertilizer N applied to wetland crop may be volatilized as oxides of N (Snyder et al. 2009).

Results of the study imply that the seasonal split application of cattle manure in small doses to wetland vegetable crops as a mitigation measure for reducing the emission of $\mathrm{N}_{2} \mathrm{O}$ from agricultural sources is effective during the first two seasonal split applications. Any further seasonal split applications of cattle manure in smaller doses to wetland vegetable crops cannot act as an effective crop management practice that reduces the emission of $\mathrm{N}_{2} \mathrm{O}$ from soil.

\section{Effect of single and seasonal split application of manure on plant dry matter yield and soil $\mathrm{N}$ uptake}

The nitrogen use efficiency (NUE) by the wetland vegetable crops could conceivably limit the loss of $\mathrm{N}$ from applied manure through gaseous emissions of $\mathrm{N}_{2} \mathrm{O}$ from soil. $\mathrm{N}$ is often cited as a limiting factor for vegetable growth in sub-tropical Africa. However, under conditions of elevated soil $\mathrm{N}$, vegetable crops exhibit luxury consumption of $\mathrm{N}$, leading to elevated tissue $\mathrm{N}$ concentration. While this pool of plant $\mathrm{N}$ may have benefits for vegetable plants if light levels change, it may also increase the risk of vegetable aboveground biomass quality (De Lannoy 2001). The differences between dry matter and uptake of $\mathrm{N}$ by the crops subjected to single basal applications and those receiving split applications of manure was smaller at the end of the experiment. This trend in the uptake of $\mathrm{N}$ by the crops is attributable to the initial abundance of $\mathrm{N}$-rich easily decomposable organic compounds in the manure in plots that received single applications of cattle manure in four cropping events. Available forms of $\mathrm{N}$ became abundant in the wetland soil upon microbial decomposition of the nitrogenous compound pools, which increased root growth for the uptake of $\mathrm{N}$.

The vegetable plots amended with split applications at every cropping event had initially insufficient $\mathrm{N}$ due to the limited quantities of manure added to create a larger net balance of mineralized $\mathrm{N}$ for uptake by the poorly developed root systems of the crops. The introduction of easily degradable C-rich materials in soil may have triggered a burst of microbial growth and activity that placed a burden on the limited quantities of mineralized $\mathrm{N}$ thereby depleting it significantly. Despite the comparatively narrow $\mathrm{C}: \mathrm{N}$ ratio in the applied manure (Table 2, C:N ratio of 16.8:1), the quantities of $\mathrm{N}$ which was limited by the mass of manure applied in small doses may have been insufficient to introduce relatively large net balances of mineralized $\mathrm{N}$ after immobilization by microbes (Markewich et al. 2010), immobilization by reactive phenols from lignin degradation (Snyder et al. 2009; Kamaa et al. 2011), emissions by denitrification (Ma et al. 2007; Vasileiadou et al. 2011) and $\mathrm{N}$ loss by nitrate leaching (Johnson et al. 2005; Berdad-Haughn et al. 2006). The net result was a greater uptake of $\mathrm{N}$ in plots that received single basal 
applications of 15 and $30 \mathrm{Mg}$ low $\mathrm{N}$ manure over that in vegetable plots that were subjected to split applications of 3.75 and $7.5 \mathrm{Mg}$ low $\mathrm{N}$ manure observed in this study.

Increased dry matter accumulations on plots subjected to higher cattle manure applications was followed by higher uptake of $\mathrm{N}$ from the applied fertilizers (Table 7). Consequently, plots that were amended with higher rates of manure applications effectively sequestered $\mathrm{N}$ that may be exposed to denitrification and the associated emissions of $\mathrm{N}_{2} \mathrm{O}$. With improved accumulations of dry matter and $\mathrm{N}$ uptake in plots subjected to higher manure applications, the applied $\mathrm{N}$ in manure was effectively sequestered from the wetland soil where it may be subjected to loss through emissions of $\mathrm{N}_{2} \mathrm{O}$. This implies that when agronomic practices are improved through manure applications, the loss of $\mathrm{N}$ in $\mathrm{N}_{2} \mathrm{O}$ emissions may significantly decrease.

\section{Conclusions}

Generally, it can be concluded that the seasonal application of cattle manure in small doses as a crop management mitigation measure for reducing the emissions of $\mathrm{N}_{2} \mathrm{O}$ from soil is effective at least up to the second seasonal split application. Thereafter, seasonal split applications of manure in smaller doses for every cropping event cannot reduce the losses of $\mathrm{N}$ from wetland soil in emissions of $\mathrm{N}_{2} \mathrm{O}$. The improved uptake of $\mathrm{N}$ by the wetland vegetable crops can limit the loss of $\mathrm{N}$ from applied manure through gaseous emissions of $\mathrm{N}_{2} \mathrm{O}$ from soil.

Generally, the proportion of applied $\mathrm{N}$ lost as $\mathrm{N}_{2} \mathrm{O}$ was higher in the rape crop than in the tomato crop. It can be concluded that rape and possibly other similar leafy vegetables production has a greater potential to emit $\mathrm{N}_{2} \mathrm{O}$ into the atmosphere than the production of tomatoes in wetlands when cattle manure is used as a fertilizer. The loss of $\mathrm{N}$ in emissions of $\mathrm{N}_{2} \mathrm{O}$ expressed per unit mass of harvested dry matter yield of rape and tomato crops decreases significantly with increasing manure application rates, dry matter yield and $\mathrm{N}$ uptake. Improved agronomic practices for increased crop productivity can be used as a mitigation factor for reducing the contribution of agriculture in the global emissions of $\mathrm{N}_{2} \mathrm{O}$.

\footnotetext{
Abbreviations

AGRITEX: agriculture, technical and extension; ANOVA: analysis of variance; CA: California; DM: dry matter; FAO: Food and Agriculture Organization; Fn: fluxes of nitrous oxide; IPCC: International Panel for Climate Change; LSD: least significant difference; Mg: milligram; NUE: nitrogen use efficiency; TX: Texas; UK: United Kingdom; USDA: United States Department of Agriculture; Wl: Wisconsin.
}

\section{Authors' contributions}

This article is one of the five field experiments which were carried out by three scientists for a Ph.D. degree. The overall objective of this study was to determine the effect of wetland cropping amended with mineral nitrogen fertilizer and cattle manure on $\mathrm{N}_{2} \mathrm{O}$ emissions and nitrate leaching. JM: He was the main researcher in spearheading the two season field experiments. JM was a PhD student at that time. All the field work, data collection and analysis, research write-up was done by him. JN: He was the main academic supervisor. The field experiment design and layouts were done under his supervision including research write-up, correcting and editing. MW: Thesis writing on the research was a very difficult business. Menas worked tirelessly in guiding this research write, data analysis especially statistical procedures. He was there right from the beginning up to the end of the field experiments. All authors read and approved the final manuscript.

\section{Author details}

${ }^{1}$ Department of Land and Water Resources Management, Faculty of Natural Resources Management and Agriculture, Midlands State University, Private Bag 9055, Gweru, Zimbabwe. ${ }^{2}$ Department of Environmental Science and Technology, School of Agricultural Sciences and Technology, Chinhoyi University of Technology, P.O. Box 7724, Chinhoyi, Zimbabwe. ${ }^{3}$ Department of Soil Science and Agricultural Engineering, Faculty of Agriculture, University of Zimbabwe, Mount Pleasant, P.O. Box MP 167, Harare, Zimbabwe. 


\section{Acknowledgements}

This research was made possible through funding by the Research Board of the Midlands State University. Most of the laboratory analysis was done in the Department of Chemical Technology of the same university.

\section{Competing interests}

The authors declare that they have no competing interests.

\section{Ethical standard}

The authors can confirm that they have read and understood the contents of the section on Compliance with Ethical Standards of the journal. In the disclosure of potential conflicts of interest, we can confirm that the authors have no conflicts of interest (either real or perceived) in the processes of data collection and analysis that lead to the compilation of the results and the conclusions derived from these results. Our study did not involve animal subjects. Neither did the study include human subjects. We have unreservedly acknowledged the assistance from our university grants. In the above, the authors have disclosed all relationships or interests that could have direct or potential influence or impart bias on the work.

Received: 5 September 2015 Accepted: 3 March 2016

Published online: 08 April 2016

\section{References}

Berdad-Haughn A, Matson AL, Pennock DJ (2006) Land use effects on gross N mineralization, nitrification and $\mathrm{N}_{2} \mathrm{O}$ emissions in ephemeral wetlands. Soil Biol Biochem 38:3398-3406

Billy C, Billen G, Sebilo M, Birgand F, Tournebize J (2010) N isotopic composition of leached nitrate and soil organic matter as an indicator of denitrification in a sloping drained agricultural plot and adjacent uncultivated riparian buffer strips. Soil Biol Biochem 42:108-117

Black GG, Hartge KH (1986) Bulk density. Methods of soil analysis. Part 3. ASA, Madison

Bouyoucos GJ (1965) Hydrometer method improved for making particle size analysis of soils. Agron J 27:738-741

Bremner JM (1996) N total. In: Sparks DL et al (eds) Methods of soil analysis: part 3. Chemical methods, no. 5 in the Soil Science Society of America. Book series Soil Science Society of America, American Society of Agronomy, Madison, pp 1085-1121

Bremner JM, Mulvaney CS (1982) N-total. In: Page AL (ed) Methods of soil analysis. Agronomy series no. 9, part 2. American Society of Agronomy, Madison, pp 595-622

Conrad R, Seiler W, Bunse G (1983) Factors influencing the loss of fertilizer N into the atmosphere as $\mathrm{N}_{2} \mathrm{O}$. Geophys Res 88:6709-6718

De Lannoy G (2001) Vegetables: pumpkins. In: Raemaekers RH (ed) Crop production in tropical Africa. Directory General for International Cooperation (DGIC), Brussels, pp 459-461

Food and Agriculture Organization (1988) FAO/UNESCO soil map of the world, revised legend, with corrections and updates. World Soil Resources Report no. 60, FAO, Rome (reprinted with updates as technical paper 20, ISRC. Wageningen, The Netherlands, 1997, p 140)

Galle B, Weslien P, Samuelsson J, Klemedtsson AK, Klemedtsson I (2003) An automatic field chamber system based on FTIR GC analysis, applied in measurements of $\mathrm{N}_{2} \mathrm{O}$ and $\mathrm{CO}_{2}$ emission from an organic soil. Eur J Soil Sci 54:234-248

GenStat Discovery Edition 3 (2003) GenStat for windows (7th Edition) Introduction. VSN International, Oxford, UK GenStat VSNI (2011) GenStat for Windows, 5th edn. VSNI International, Wilkinson House, Jordan Hill Road, Oxford, London, UK

Holland EA, Robertson GP, Greenberg J, Groffman P, Boone R, Gosz J (1999) Soil $\mathrm{CO}_{2}, \mathrm{~N}_{2} \mathrm{O}$ and $\mathrm{CH}_{4}$ exchange. In: Robertson GP, Bledsoe CS, Coleman DC, Sollins P (eds) Standard soil methods for long-term ecological research. Oxford Press, New York, USA, pp 185-201

Hutchinson GL, Livingston GP (1993) Use of chamber systems to measure trace gas fluxes. In: Harper LA et al (eds) Agroecosystem effects on radiatively important trace gases and global climate change. ASA special publication no. 55. ASA, CSSA and SSSA, Madison, pp 781-825

IPCC (2001) Technical summary. In: Houghton JT, Ding Y, Griggs DJ, Noguer M, van der Linden PJ, Dai X, Maskell K, Johnson CA (eds) Climate change 2001: the scientific basis. Contribution of working group I of the international panel on climate change. Cambridge University Press, Cambridge, pp 321-346

Jassal RS, Black TA, Roy R, Ethier G (2011) Effect of N fertilization on soil CH4 and $\mathrm{N}_{2} \mathrm{O}$ fluxes, and soil and bole respiration. Geoderma 162:182-186

Johnson JMF, Roycosky DC, Almaras RR, Sauer TJ, Venterea RT, Dell CJ (2005) Greenhouse gas contribution and mitigation potential of agriculture in the central USA. Soil Tillage Res 83:73-94

Kaiser E-A, Munch JC, Heinemeyer O (1996) Importance of soil cover box area for the determination of $\mathrm{N}_{2} \mathrm{O}$ emissions from arable soils. Plant Soil 181:185-192

Kamaa M, Mburu H, Blanchart E, Chibole L, Chotte JL, Kibunja C, Lesueur D (2011) Effects of organic and inorganic fertilization on soil bacterial and fungal microbial diversity in the Kabete long-term trial, Kenya. Biol Fertil Soils 47:315-32

Kroetze C, Aerts R, Van Dam D, Van Der Hoek K, Hofschreuder P, Hoosbeek M, de Klein J, Kros H, Van Oene H, Oenema O, Tietema A, Van Der Veeren R, de Vries W (2003) Uncertainities in the fate of N. An overview of sources of uncertainty illustrated with a Dutch case study. Nutr Cycl Agroecosyst 66:43-69

Lesschen JP, Velthof GL, Vries W, de Kros J (2011) Differentiation of nitrous oxide emission factors for agricultural soils. Environ Pollut 159:3215-3222

Lin J, Hu RJ, Zhao JR, LeiLei MS (2011) Nitrous oxide emissions from rape field as affected by nitrogen fertilizer management: a case study in Central China. Atmos Environ 45:1775-1779

Ma WK, Schautz A, Fishback LE, Bedard-Haughn A, Farrell RE, Siciliano SD (2007) Assessing the potential of ammonia oxidizing bacteria to produce nitrous oxide in soils of high arctic lowland ecosystem on Devon Island, Canada. Soil Biol Biochem 39:2001-2013 
Mathias AD, Blackmer AM, Bremmer JM (1980) A simple chamber technique for field measurement of emissions of nitrous oxide from soils. J Environ Qual 9:251-256

Mapanda F, Wuta NyamangaraJ, Rees RM (2012) N leaching and indirect nitrous oxide emissions from fertilized croplands in Zimbabwe. J Nutr Cycl Agroecosyst. doi:10.1007/s10705-9528-7

Markewich HA, Pell AN, Mbugua DM, Cherney DJR, Es HM, van Lehmann J, Robertson JB (2010) Effects of storage methods on chemical composition of manure and manure decomposition in soil in small-scale Kenyan systems. Agr Ecosyst Environ 139:134-141

Meyer CP, Galbally IE, Wang Y, Weeks IA, Jamie I, Griffith DWT (2001) Two automatic chamber techniques for measuring soil atmosphere exchanges of trace gases and results of their use in the Oasis field experiment. CSIRO Publishing; Atmosphere Research Technical Paper No. 51, pp 1-33

Mosier AR, Kroetze C (1999) Contributions of agroecosystems to the global atmospheric $\mathrm{N}_{2} \mathrm{O}$ budget. In: Desjardins RL, Keng JC, Haugen-Kozyra K (eds) Proceedings of the international workshop of reducing nitrous oxide emissions from agroecosystems, Banff, AB, Canada, March 3-5. Agriculture and Agri-Food Canada, Research Branch, Alberta Agriculture, Food and Rural Development, Conservation and Development Branch, pp 3-15

Mosier AR, Mack L (1980) Gas chromatographic system for precise and rapid analysis of nitrous oxide. Soil Sci Soc Am J 44:1121-1123

Mosier A, Kroeze C, Nevison C, Osnema O, Seitzinger S, van Cleemput O (2003) Closing the $\mathrm{N}_{2} \mathrm{O}$ budget: nitrous oxide emissions through the agricultural N cycle. Nutr Cycl Agroecosyst 52:225-248

Mugandani R, Wuta M, Makarau A, Chipindu B (2012) Re-classification of agroecological regions of Zimbabwe in conformity with climate variability and change. Afr Crop Sci J 20:361-369

Munoz C, Paulino L, Monreal C, Zagal E (2010) Greenhouse gas ( $\mathrm{CO}_{2}$ and $\mathrm{N}_{2} \mathrm{O}$ ) emissions from soils: a review. Chil JAR 70:485-497

Mutsamba EF, Nyagumbo I, Mafongoya PL (2012) Dry season crop residue management using organic livestock repellents under conservation agriculture in Zimbabwe. J Org Syst 7:5-13

Nelson DW, Sommers LE (1982) Methods of soil analysis. In: Page AL (ed) Total C, organic C and organic matter. Agronomy series no. 9, Part 2. American Society of Agronomy, Inc., American Society of Soil Science, Inc., Madison, Wisconsin, USA, pp 539-579

Nelson DW, Sommers LE (1996) Methods of determination of total organic carbon (TOC) in soils and sediments. In: Page AL (ed) Total C, organic C and organic matter. Environmental Protection Agency, Las Vegas, pp 456-461

Nyamapfene KW (1991) Soils of Zimbabwe. Nehanda, Harare, pp 75-79

Owen R, Verbeek K, Jackson J, Steenhuis M (1995) Water management, cropping and soil potentials for smallholder farming in the wetlands. University of Zimbabwe, Harare

Robertson GP, Wedin D, Groffman PM, Blair JM, Holland EA, Nadelhoffer KJ, Haris D (1999) Soil carbon and nitrogen availability: nitrogen mineralization, nitrification, and soil respiration potentials. In: Robertson GP et al (eds) Standard soil methods for long-term ecological research. Oxford University Press, New York, pp 258-271

Saggar S (2010) Special issue: estimation of nitrous oxide emission from ecosystems and its mitigation technologies. Agric Ecosyst Environ 136:189-365

Smith P (2012) Agricultural greenhouse gas mitigation potential globally, in Europe and in the UK: what have we learnt in the last 20 years? Glob Chang Biol 18:35-43

Snyder CS, Bruulsema TW, Jensen TL, Fixen PE (2009) Review of greenhouse gas emissions from crop production systems and fertilizer management effects. Agric Ecosyst Environ 133:247-266

Soil Survey Staff (1992) Keys to the soil taxonomy, 5th edn. SMSS technical monograph no. 19, Pocahontas Press Inc., Blacksburg, Virginia, USA, p 541

Vasileiadou E, Heimeriks G, Petersen AC (2011) Exploring the impact of the IPCC assessment reports on science. Environ Sci Policy 14:1052-1061

Wang GS, Chen SL, Wang GS, Chen SL (2012) A review on parameterization and uncertainty in modeling greenhouse gas emissions from soil. Geoderma 170:206-216

Wrage N, Velthof GL, Laanbroek HJ, Oenema O (2004) Nitrous oxide production in grassland soils: assessing the contribution of nitrifier dentrification. Soil Biol Biochem 36:229-236

Yates TT, Si BC, Farrell RE, Pennock DJ (2006) Probability distribution and spatial dependence of nitrous oxide emission: temporal change in hummocky terrain. Soil Sci Soc Am J 70:753-762

\section{Submit your manuscript to a SpringerOpen ${ }^{\circ}$ journal and benefit from:}

- Convenient online submission

- Rigorous peer review

- Immediate publication on acceptance

- Open access: articles freely available online

- High visibility within the field

- Retaining the copyright to your article

Submit your next manuscript at $\boldsymbol{\nabla}$ springeropen.com 